\title{
High Temperature Steam Electrolysis Materials Degradation: Preliminary Results of Corrosion Tests on Ceramatec Electrolysis Cell Components
}

Paul Demkowicz

Prateek Sachdev

Kevin DeWall

Pavel Medvedev

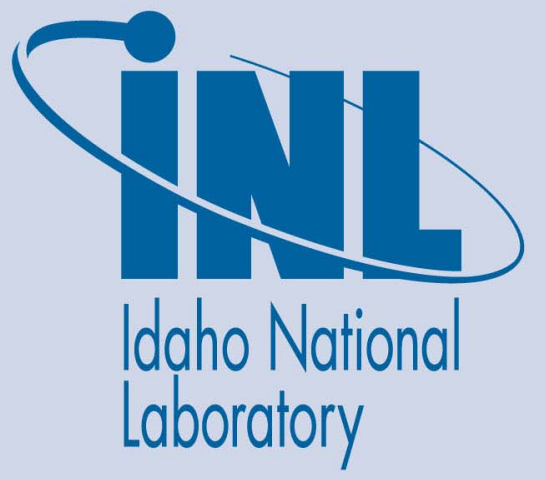

June 2007

The INL is a U.S. Department of Energy National Laboratory operated by Battelle Energy Alliance 
INL/EXT-07-13622

\title{
High Temperature Steam Electrolysis Materials Degradation: \\ Preliminary Results of Corrosion Tests on Ceramatec Electrolysis Cell Components
}

\author{
Paul Demkowicz \\ Prateek Sachdev \\ Kevin DeWall \\ Pavel Medvedev
}

June 2007

\begin{abstract}
Idaho National Laboratory
Idaho Falls, Idaho 83415
\end{abstract}

Prepared for the

U.S. Department of Energy

Office of Nuclear Energy

Under DOE Idaho Operations Office

Contract DE-AC07-05ID14517 


\begin{abstract}
Corrosion tests were performed on stainless steel and nickel alloy coupons in $\mathrm{H}_{2} \mathrm{O} / \mathrm{H}_{2}$ mixtures and dry air to simulate conditions experienced in high temperature steam electrolysis systems. The stainless steel coupons were tested bare and with one of three different proprietary coatings applied. Specimens were corroded at $850^{\circ} \mathrm{C}$ for $500 \mathrm{~h}$ with weight gain data recorded at periodic intervals. Post-test characterization of the samples included surface and cross-section scanning electron microscopy, grazing incidence x-ray diffraction, and area-specific resistance measurements. The uncoated nickel alloy outperformed the ferritic stainless steel under all test conditions based on weight gain data. Parabolic rate constants for corrosion of these two uncoated alloys were consistent with values presented in the literature under similar conditions. The steel coatings reduced corrosion rates in $\mathrm{H}_{2} \mathrm{O} / \mathrm{H}_{2}$ mixtures by as much as $50 \%$ compared to the untreated steel, but in most cases showed negligible corrosion improvement in air. The use of a rare-earth-based coating on stainless steel did not result in a significantly different area specific resistance values after corrosion compared to the untreated alloy. Characterization of the samples is still in progress and the findings will be revised when the complete data set is available.
\end{abstract}




\section{TABLE OF CONTENTS}

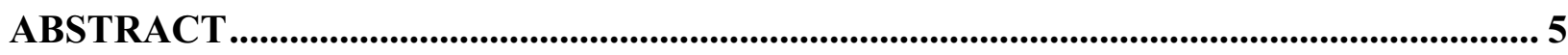

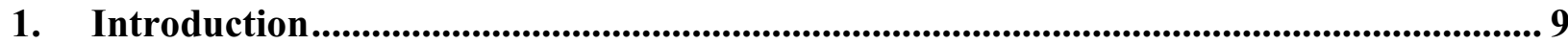

2. Experiment Description.................................................................................................... 10

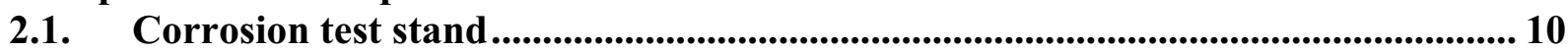

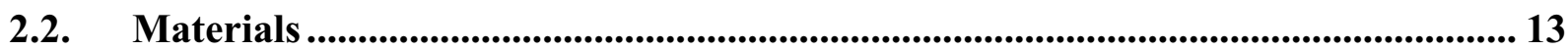

2.3. Corrosion experiments .................................................................................................... 14

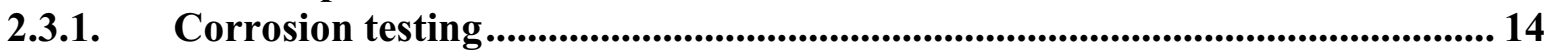

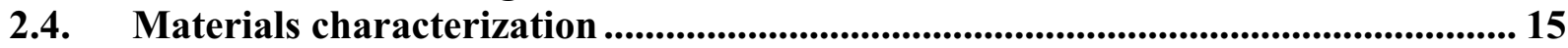

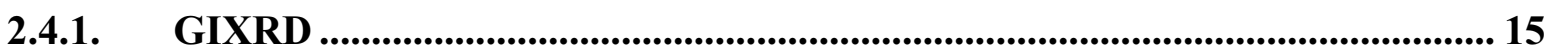

2.4.2. SEM .................................................................................................................... 16

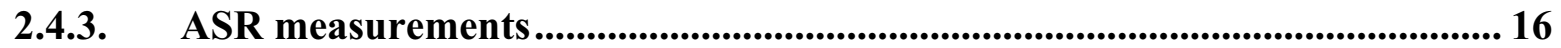

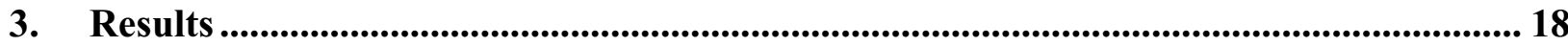

3.1. System performance ....................................................................................................... 18

3.2. Weight gain...................................................................................................................... 19

3.2.1. Reaction kinetics ................................................................................................... 23

3.3. Corrosion microstructures.......................................................................................... 26

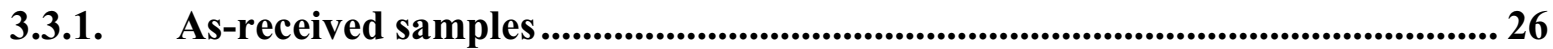

3.3.2. Steam/hydrogen corrosion .......................................................................... 27

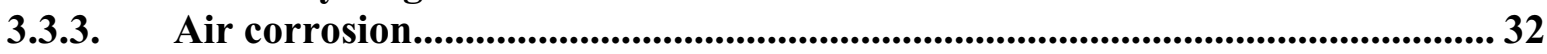

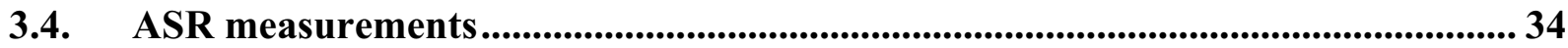

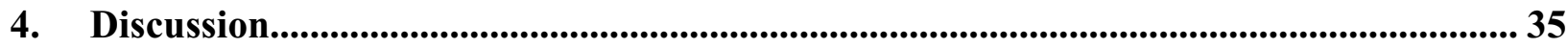

4.1. Untreated alloys ....................................................................................................... 35

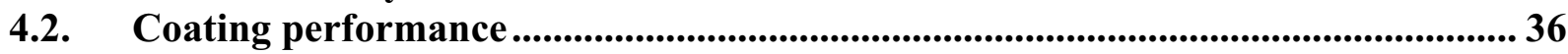

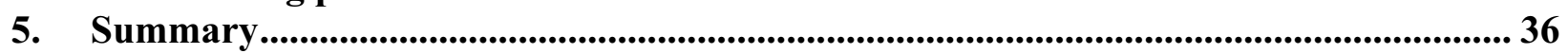

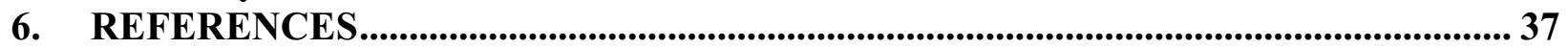




\section{FIGURES}

Figure 1. Conceptual drawing of the corrosion experiment. .................................................. 11

Figure 2. Schematic diagram of the gas supply system....................................................... 12

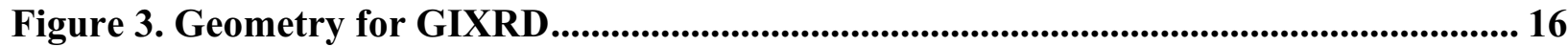

Figure 4. High temperature area specific resistivity measurement apparatus.................... 17

Figure 5. Schematic diagram of area specific resistivity meausurement.............................. 18

Figure 6. End of test weight gains from 500 h corrosion tests. ........................................ 20

Figure 7. Weight gain data for coated FSS samples from two different coating lots. Air corrosion data are shown on the left, $\mathrm{H}_{2} \mathrm{O} / \mathrm{H}_{2}$ corrosion data are shown on the right. The coating lot and the corrosion test number are given for each data point............................ 22

Figure 8. Weight gain data for coated $440 \mathrm{C}$ stainless steel specimens from Test 1

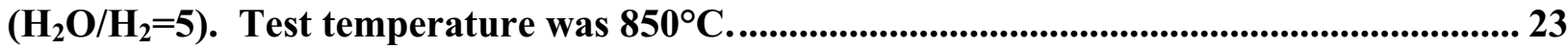

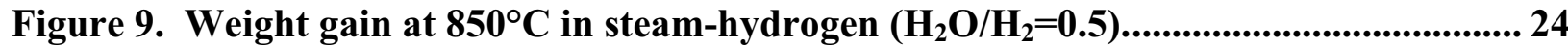

Figure 10. Weight gain at $850^{\circ} \mathrm{C}$ in dry air. ..............................................................25

Figure 11. Weight gain data from Test $2\left(\mathrm{H}_{2} \mathrm{O} / \mathrm{H}_{2}=0.5\right)$ for uncoated FSS and FSS+Coating

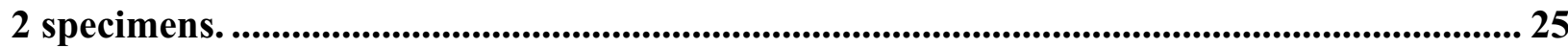

Figure 12. Surface microstructure of FSS + Coating 1 sample. ........................................ 26

Figure 13. Surface microstructure of FSS + Coating 2 sample. ............................................. 27

Figure 14. Surface microstructure of FSS + Coating 3 sample. Two different types of surface morphology are shown in the magnified images on the right. ................................. 27

Figure 15. Grazing incidence $x$-ray diffraction patterns of as-received samples FSS +

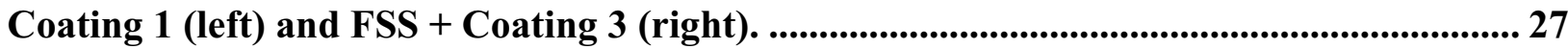

Figure 16. Surface micrographs of uncoated FSS exposed to a $\mathrm{H}_{2} \mathrm{O} / \mathrm{H}_{2} / \mathrm{N}_{2}$ mixture

$\left(\mathrm{H}_{2} \mathrm{O} / \mathrm{H}_{2}=10\right)$ at $850^{\circ} \mathrm{C}$ for $500 \mathrm{~h}$ (Test 4). ................................................................................... 28

Figure 17. Surface micrographs of FSS + Coating 1 exposed to a $\mathrm{H}_{2} \mathrm{O} / \mathrm{H}_{2} / \mathrm{N}_{2}$ mixture

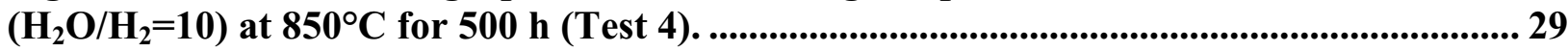

Figure 18. Surface micrographs of FSS + Coating 2 exposed to a $\mathrm{H}_{2} \mathrm{O} / \mathrm{H}_{2} / \mathrm{N}_{2}$ mixture

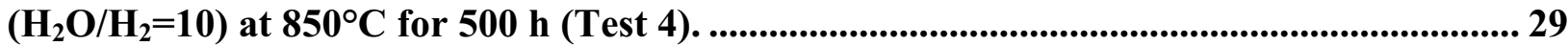

Figure 19. Surface micrographs of FSS + Coating 3 exposed to a $\mathrm{H}_{2} \mathrm{O} / \mathrm{H}_{2} / \mathrm{N}_{2}$ mixture $\left(\mathrm{H}_{2} \mathrm{O} / \mathrm{H}_{2}=10\right)$ at $850^{\circ} \mathrm{C}$ for $500 \mathrm{~h}$ (Test 4). .................................................................... 29

Figure 20. Surface micrographs of uncoated $\mathrm{NiCr}$ exposed to a $\mathrm{H}_{2} \mathrm{O} / \mathrm{H}_{2} / \mathrm{N}_{2}$ mixture $\left(\mathrm{H}_{2} \mathrm{O} / \mathrm{H}_{2}=10\right)$ at $850^{\circ} \mathrm{C}$ for $500 \mathrm{~h}$ (Test 4). .......................................................................30

Figure 21. Cross-sectional micrographs of coated FSS specimens exposed to an $\mathrm{H}=\mathrm{O} / \mathrm{H}_{2} / \mathrm{N}_{2}$ mixture $\left(\mathrm{H}_{2} \mathrm{O} / \mathrm{H}_{2}=0.5\right)$ at $850^{\circ} \mathrm{C}$ for $500 \mathrm{~h}$ (Test 2)......................................................... 30 Figure 22. Grazing incidence x-ray diffraction patterns for samples exposed to $\mathrm{H}_{2} \mathrm{O} / \mathrm{H}_{2} / \mathrm{N}_{2}$ mixtures $\left(\mathrm{H}_{2} \mathrm{O} / \mathrm{H}_{2}=5\right)$ at $850{ }^{\circ} \mathrm{C}$ for $500 \mathrm{~h}$ (Test 1)................................................................. 31 Figure 23. Surface micrographs of uncoated FSS exposed to dry air at $850^{\circ} \mathrm{C}$ for $500 \mathrm{~h}$

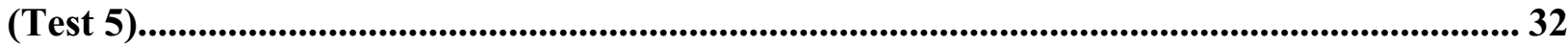

Figure 24. Surface micrographs of FSS + Coating 2 exposed to dry air at $850^{\circ} \mathrm{C}$ for $500 \mathrm{~h}$ (Test 3).

Figure 25. Surface micrographs of FSS + Coating 3 exposed to dry air at $850^{\circ} \mathrm{C}$ for $500 \mathrm{~h}$ (Test 3).................................................................................................................................................... 33

Figure 26. GIXRD patterns for NiCr and FSS after $500 \mathrm{~h}$ exposure to air at $850^{\circ} \mathrm{C}$ (Test 3 ). 
Figure 27. ASR measurements of FSS and FSS + Coating 1 specimens, performed after specimens were heated in steam/hydrogen $\left(\mathrm{H}_{2} \mathrm{O} / \mathrm{H}_{2}=0.5\right)$ at $850^{\circ} \mathrm{C}$ for 500 hours (Test 2). 34 Figure 28. ASR measurements of a FSS + Coating 1 specimen, performed after specimens were heated in steam/hydrogen $\left(\mathrm{H}_{2} \mathrm{O} / \mathrm{H}_{2}=0.5\right)$ at $850^{\circ} \mathrm{C}$ for 500 hours (Test 3)..................... 35

\section{TABLES}

Table 1. Number of sample coupons tested in each corrosion experiment. All samples were from Lot 1 except as noted................................................................................................................ 13

Table 2. Summary of corrosion test atmospheres.............................................................................. 14

Table 3. Target conditions for steam/hydrogen corrosion tests. ................................................ 15

Table 4. Temperatures of the water bath for $500 \mathrm{~h}$ steam/hydrogen corrosion tests........... 18

Table 5. Actual experimental conditions for steam/hydrogen corrosion tests........................ 19

Table 6. Notes on the weight gain data from Phase I tests....................................................... 20

Table 7. Parabolic rate constants for oxidation in $\mathrm{H}_{2} \mathrm{O} / \mathrm{H}_{2}$ (Test 2) and dry air (Test 3) at $\mathbf{8 5 0}^{\circ} \mathrm{C}$

Table 8. Crystalline phases at corroded sample surfaces identified with GIXRD. Samples were exposed to $\mathrm{H}_{2} \mathrm{O} / \mathrm{H}_{2} / \mathrm{N}_{2}$ mixtures $\left(\mathrm{H}_{2} \mathrm{O} / \mathrm{H}_{2}=5\right)$ at $850^{\circ} \mathrm{C}$ for $500 \mathrm{~h}$ (Test 1). Additional ceramic oxide phases (present in the as-prepared coatings) were also observed on the FSS specimens with Coating 2 and Coating 3. 


\title{
High Temperature Steam Electrolysis Materials Degradation:
}

\author{
Results of Corrosion Tests on Ceramatec Electrolysis Cell Components
}

\section{Introduction}

High temperature steam electrolysis (HTSE) for the production of hydrogen using solid oxide electrolysis cells (SOECs) is the subject of recent research and development efforts. ${ }^{1,2}$ A single electrolysis cell consists of an anode, cathode, and a solid oxygen ion conducting electrolyte. In the planar configuration, these devices can be arranged in multiple-cell stacks with the individual cells joined by electrically conducting interconnects. The operating temperatures of SOECs (as high as $800-900^{\circ} \mathrm{C}$ ) and the atmospheres within the cell (steam-hydrogen feed gas mixtures on the cathode side and oxygen-rich gas mixtures on the anode side) can be very demanding from a materials degradation standpoint. The commercial use of SOECs will require extended operation ( $\geq 40,000$ hours), and the materials must exhibit minimal degradation over these time scales. Corrosion of the various electrolytic cell components will result in reduced performance and shortened device lifetimes, and therefore presents significant challenges.

While research on SOEC materials has been somewhat limited in the technical literature, the electrolysis cell architecture, materials of construction, and operating conditions bear many similarities to solid oxide fuel cells (SOFCs), which have been the subject of extensive R\&D over the last 20 years. ${ }^{3,4}$ Therefore a great deal of the materials development for fuel cells has direct applicability to SOECs.

Interconnect materials must be electrically conductive, resistant to high temperature corrosion, impermeable to the anodic and cathodic gases, and have a thermal expansion coefficient match to the other cell materials, most notably the solid oxide electrolyte (typically stabilized zirconia). Both ceramic and metallic materials have been explored as interconnect materials. ${ }^{5,6}$ Metallic candidates have the advantages of mechanical strength and ease of manufacture. The development of metallic interconnect materials has focused on materials that form stable, adherent oxide scales under the SOEC operating conditions, which can act as an effective barrier to further oxidative corrosion. However the additional requirement of electrical conductivity means that protective oxide layers must also have relatively high conductivities. This requirement rules out alloys that form alumina- or silica-based oxide scales, as the resistivity is much too high, and has resulted in a focus on materials forming chromium oxides. The primary metallic candidates for interconnects include high temperature nickel alloys and certain highchrome ferritic stainless steels.

In addition to metallic interconnects, certain cell stack designs require a separate metallic flow field to be employed. ${ }^{7}$ These materials are subjected to the same cathodic and anodic gas mixtures and temperatures as the interconnects. Nickel is effective as a cathode-side flow field, while Ni-Fe-Cr alloys are candidates for the anode side. 
The Idaho National Laboratory (INL) has an advanced research and development program on bench-scale SOEC systems and is preparing for continued testing on larger lab-scale and pilotscale systems. ${ }^{7,8}$ A portion of this work is being performed in conjunction with Ceramatec Inc, and involves performance testing of Ceramatec electrolysis cells. Integral to the scale-up of this technology is an understanding of materials degradation in prototypic materials over long time scales. This report describes the initial results of high temperature isothermal degradation studies of metallic components used in experimental electrolysis cells fabricated by Ceramatec.

\section{Experiment Description}

\subsection{Corrosion test stand}

The high temperature corrosion test consists of two parallel piping systems running through three furnaces so that different temperatures, component sizes, configurations, and even bi-polar corrosion measurements can be accommodated during the same experimental run. The two parallel loops share a common gas supply system and are then completely separate through the furnaces and out the laboratory vents. A conceptual drawing of the $\mathrm{H}_{2} \mathrm{O} / \mathrm{H}_{2} / \mathrm{N}_{2}$ loop is shown in Figure 1. The $\mathrm{O}_{2} / \mathrm{N}_{2} /$ air loop is the same, without the humidifier. The following discussion provides a description of the major systems making up the high temperature corrosion test.

The piping and instrumentation diagram of the system is shown in Figure 2. There are no isolation valves in the piping from the furnace to the vent so over pressurization due to heating is not possible. There are no tube fittings located inside the furnaces or kilns. Two vents are used, one for oxygen mixtures and one for hydrogen mixtures. The vents are located in the laboratory approximately $30 \mathrm{ft}$ apart. The piping system is made from standard Swagelok-type fittings and tubing with pressure ratings in excess of 1000 psi.

Five gases make up the gas supply: hydrogen, nitrogen, compressed air, oxygen and helium. These gasses (except compressed air) are supplied from compressed gas cylinders. Compressed air is supplied from building utilities. The experimental campaigns are long in duration and demand a continuous gas supply, therefore two bottles of each gas type are connected to a change-over regulator assembly which allows bottle change-out without loss of gas flow.

The discharge from the gas supply system feeds the mass flow controllers, mixing valves, and gas humidifier. The gas mixing system produces the desired gas mixtures for the experimental campaign. A humidifier is used in the $\mathrm{H}_{2} \mathrm{O} / \mathrm{H}_{2} / \mathrm{N}_{2}$ loop to add water to gas flow stream. Mass flow controllers assure steady supply during the long duration experiments. The $\mathrm{H}_{2} \mathrm{O} / \mathrm{H}_{2} / \mathrm{N}_{2}$ lines are heat-traced to prevent steam condensation.

The gas mixing system feeds the furnace manifold which can divert and balance flow to the three testing furnaces. Corrosion samples within the three furnaces are contained in gas-tight metal containers. The tube furnace was used exclusively in the current corrosion experiments. Metal tubes run the length of the furnace and small sample coupons are placed inside these tubes during experiments. The larger internal volume of the kilns will allow custom reaction vessels to be employed and testing of larger samples. Test gas will be introduced in the bottom and vented out the top. 
The tube furnace is a Lindberg Model 55666-B-COM with a maximum operating temperature of $1100^{\circ} \mathrm{C}$. It has $36^{\prime \prime}$ long heated chamber with three zones of control: first zone 9", middle zone 18 ", last zone 9". The total power input of $11 \mathrm{~kW}$ is housed in a double-shell construction. The furnace has an On/Off Circuit breaker and is designed for operation on $240 \mathrm{~V} / 1 \mathrm{Phase} / 60 \mathrm{~Hz}$ requiring $60 \mathrm{amp}$ service. The tube furnace is controlled with 3 separate Yokogawa UP150 programmable controllers with dual LED display of setpoint and actual temperature. The tube furnace also has separate over-temperature protection. This consists of a digital high-limit controller with separate thermocouple and magnetic contactor disconnect on the heating elements.

An overhead gas monitoring system has been employed in the laboratory for safety. This system monitors four gases $\left(\mathrm{CO}, \mathrm{CO}_{2}, \mathrm{H}_{2}\right.$, and $\left.\mathrm{O}_{2}\right)$, in two locations (over the corrosion experiments and steam electrolysis experiments). The system has relay outputs, display readout, visual and audible alarms, and auto dialer. The relay outputs are used to automatically shut down the experimental gas flow if any gas alarm is activated. If any gas is out of range the following will happen: the gas supply valves will shut, nitrogen purge will begin, audible alarm in the lab, and appropriate personnel will be notified.

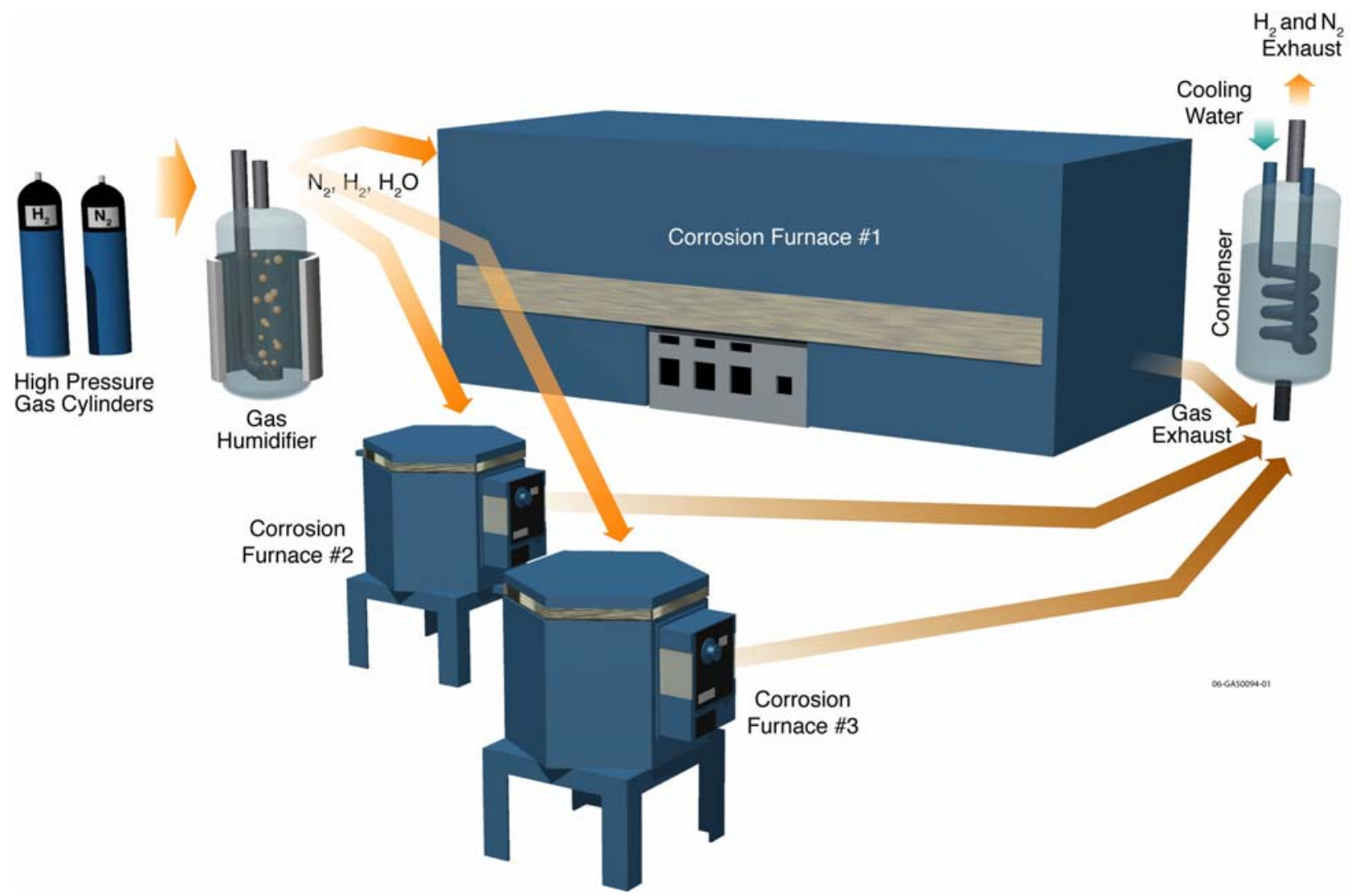

Figure 1. Conceptual drawing of the corrosion experiment. 


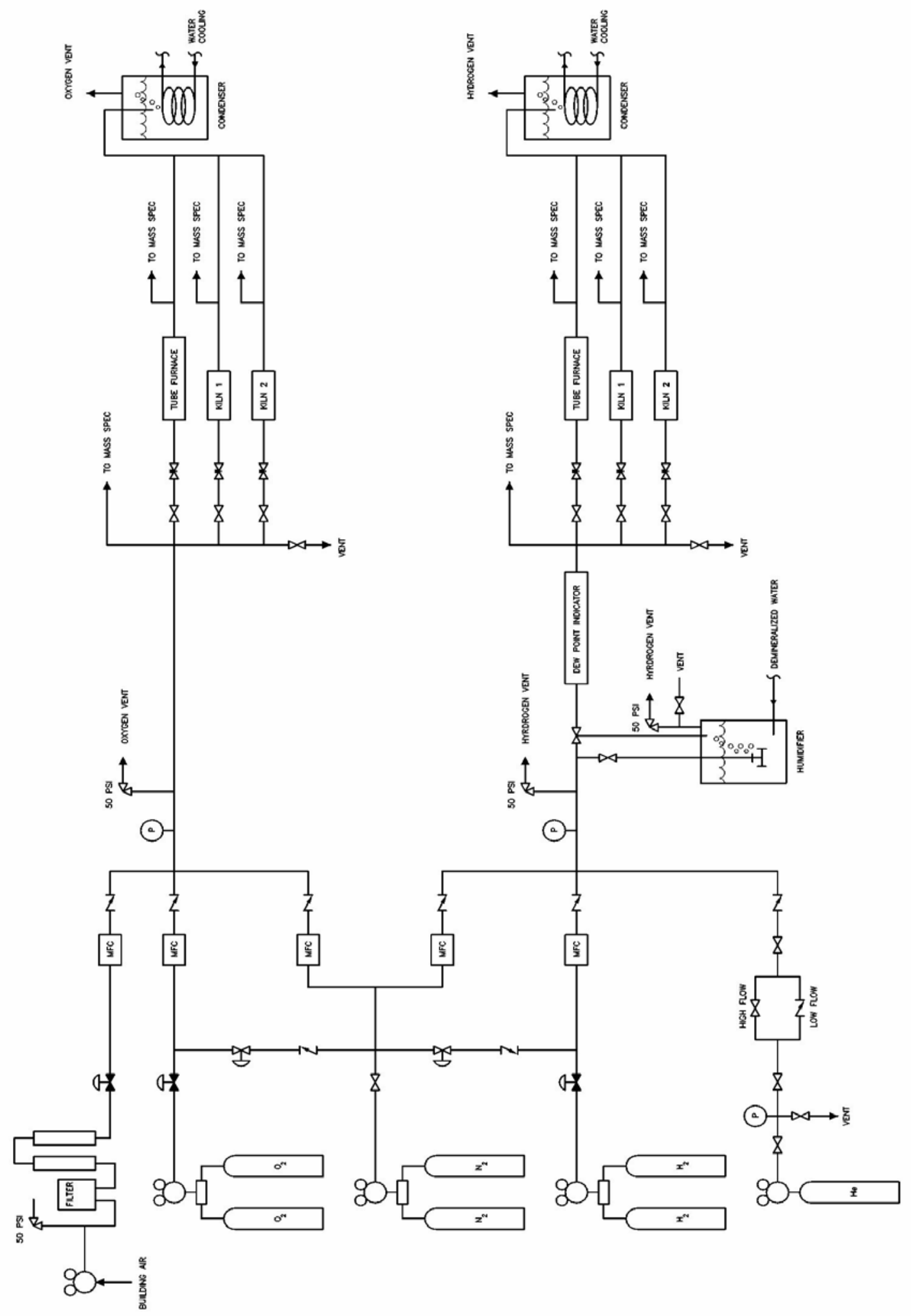

Figure 2. Schematic diagram of the gas supply system. 


\subsection{Materials}

The test materials were provided by Ceramatec as approximately $1 \mathrm{~cm} \times 1 \mathrm{~cm}$ coupons. Two base metals were tested: a commercial ferritic stainless steel with 18-20\% $\mathrm{Cr}$ (designated here "FSS") and a commercial Ni-Cr alloy (designated in this report "NiCr"). The stainless steel is used as interconnects and edge rails in Ceramatec electrolysis cells. The Ni-Cr alloy is used as the air-side flow field. The FSS base metal was also supplied with one of three different protective coatings. One was a rare-earth-based coating intended to provide a corrosion protective layer with a relatively high electrical conductivity through the formation of rare-earth oxide phases, and is used on the metallic interconnects. This coating is designated "Coating 1" or " $\mathrm{C} 1$ " in this report. The other two coatings consisted of the standard rare-earth-based coating along with additional oxide ceramic phases. These coatings are intended for use as the metallic edge rails in the electrolytic cell and are designated "Coating 2" (or "C2") and "Coating 3" (or "C3") in this report.

Two different lots of ten FSS specimens with each of the three coatings were sent from Ceramatec. Most of the corrosion tests involved specimens from the first lot, but some of the specimens from the second lot were used in the final two corrosion tests. There appeared to be a difference in corrosion behavior of the coatings from the two lots. This will be discussed in the results section. Table 1 summarizes the number of samples used in each test, and notes which lot the samples originated from. The five corrosion tests are discussed in the next section.

The bare metal samples were cleaned ultrasonically in acetone prior to corrosion testing. Coated samples were used in the as-received condition.

Table 1. Number of sample coupons tested in each corrosion experiment. All samples were from Lot 1 except as noted.

\begin{tabular}{|c|c|c|c|c|c|}
\hline \multirow{2}{*}{ Sample } & \multicolumn{5}{|c|}{ Number of coupons tested } \\
\cline { 2 - 6 } & Test 1 & Test 2 & Test 3 & Test 4 & Test 5 \\
\hline NiCr (uncoated) & 1 & 2 & 2 & 2 & 1 \\
\hline FSS (uncoated) & 1 & 2 & $2^{(\mathrm{a})}$ & 2 & 1 \\
\hline FSS + Coating 1 & 1 & 2 & 2 & 2 & $2^{(\mathrm{b})}$ \\
\hline FSS + Coating 2 & 1 & 2 & 2 & 2 & $2^{(\mathrm{c})}$ \\
\hline FSS + Coating 3 & 1 & 2 & 2 & $2^{(\mathrm{c})}$ & $2^{(\mathrm{b})}$ \\
\hline
\end{tabular}

(a) One of the samples became damaged during the test and weight gain data was rendered irrelevant

(b) Both tested samples were from Lot 2.

(c) One sample was from Lot 1 and another from Lot 2.

Corrosion Test 1 also included several 440C stainless steel specimens with each of the three coatings described in this section (specimens were also provided by Ceramatec). However, the surface area normalized weight gains of these materials were found to be greater than either the $\mathrm{NiCr}$ or FSS samples by a factor of more than 30, and Ceramatec has opted to cease their use of this material in their electrolysis cells because of it's poor corrosion performance. Testing of this material was therefore not continued for the remaining experiments, and the results will be discussed here only briefly. 


\subsection{Corrosion experiments}

\subsubsection{Corrosion testing}

Corrosion tests were performed on the sample materials in $\mathrm{H}_{2} \mathrm{O} / \mathrm{H}_{2} / \mathrm{N}_{2}$ mixtures and in dry air. The $\mathrm{H}_{2} \mathrm{O} / \mathrm{H}_{2} / \mathrm{N}_{2}$ mixtures are used to simulate the cathode-side gas mixtures in electrolysis cells currently being tested at INL and Ceramatec. On this side of the cell, the $\mathrm{H}_{2} \mathrm{O} / \mathrm{H}_{2} / \mathrm{N}_{2}$ mixture enters at the inlet and, as $\mathrm{H}_{2} \mathrm{O}$ is converted to $\mathrm{H}_{2}(\mathrm{~g})$ and $\mathrm{O}^{2-}$ ions in the solid electrolyte, becomes depleted in $\mathrm{H}_{2} \mathrm{O}$ as the gas flows toward the outlet. Current calculations indicate that for inlet mixtures with $\mathrm{H}_{2} \mathrm{O} / \mathrm{H}_{2}=10$, the outlet mixture may have $\mathrm{H}_{2} \mathrm{O} / \mathrm{H}_{2}=1$ or less. The anode side of the electrolysis cell is typically swept with air, and $\mathrm{O}_{2}(\mathrm{~g})$ is introduced via the half-cell reaction

$$
2 \mathrm{O}^{2-}=\mathrm{O}_{2}(\mathrm{~g})+4 \mathrm{e}^{-} .
$$

Eq. 1

Thus the oxygen partial pressure in the anode-side gas may range from $\sim 0.21$ (dry air) at the inlet to as high as 0.5 at the outlet. In the present set of experiments, air is used to represent the anode-side gas at the inlet.

Sample coupons were placed in a $\mathrm{ZrO}_{2}$ boat and inserted into the Hastelloy furnace tube. The boat was placed so that the samples were centered with the furnace mid-line. A small Incoloy wire attached to the $\mathrm{ZrO}_{2}$ boat was used to remove the samples from the furnace tube when necessary. For $\mathrm{H}_{2} \mathrm{O} / \mathrm{H}_{2}$ tests, a flow of helium was used to purge the system while the furnace was heated to the target temperature. Once the test temperature $\left(850^{\circ} \mathrm{C}\right)$ was reach, the flow of the appropriate $\mathrm{H}_{2} / \mathrm{N}_{2}$ gas mixture started through the bubbler at the prescribed temperature. When samples were to be removed from the furnace, the helium purge was started again and the furnace was allowed to cool to room temperature. For air tests, a constant flow of air was used throughout the tests.

Five different 500 hour tests were performed and are summarized in Table 2 . Tests $2 \& 3$ and Tests $4 \& 5$ were completed during the same furnace run by running two Hastelloy tubes through the furnace with different gas flows. While Tests 1-3 involved making intermediate weight gain measurements at periodic intervals, Tests 4 and 5 were run for $500 \mathrm{~h}$ without interruption. The target test conditions for the steam/hydrogen tests are given in Table 3. For Tests 3 and 5, the air was from the building compressed air supply with a three stage filter for particulates, oil, and water.

Table 2. Summary of corrosion test atmospheres

\begin{tabular}{|c|c|c|c|}
\hline Test \# & Atmosphere & Temp. $\left({ }^{\circ} \mathbf{C}\right)$ & Duration (h) \\
\hline 1 & $\mathrm{H}_{2} \mathrm{O} / \mathrm{H}_{2}=5$ & 850 & 500 \\
\hline 2 & $\mathrm{H}_{2} \mathrm{O} / \mathrm{H}_{2}=0.5$ & 850 & 501 \\
\hline 3 & Air & 850 & 501 \\
\hline 4 & $\mathrm{H}_{2} \mathrm{O} / \mathrm{H}_{2}=10$ & 850 & 500 \\
\hline 5 & Air & 850 & 500 \\
\hline
\end{tabular}


Table 3. Target conditions for steam/hydrogen corrosion tests.

\begin{tabular}{|c|c|c|c|c|c|c|c|c|}
\hline \multirow{2}{*}{ Test \# } & \multicolumn{2}{|c|}{$\begin{array}{l}\text { Initial flow } \\
\text { (sccm) }\end{array}$} & \multirow{2}{*}{$\begin{array}{l}\text { Bath } \\
\text { temp. } \\
\left({ }^{\circ} \mathrm{C}\right)\end{array}$} & \multicolumn{3}{|c|}{ Final composition $^{(a)}$} & \multirow{2}{*}{$\mathrm{H}_{2} \mathrm{O} / \mathrm{H}_{2}$} & \multirow{2}{*}{$\begin{array}{c}\text { Total } \\
\text { flow } \\
\text { (L/min) }\end{array}$} \\
\hline & $\mathbf{H}_{2}$ & $\mathbf{N}_{2}$ & & $\% \mathrm{H}_{2} \mathrm{O}$ & $\% \mathrm{H}_{2}$ & $\% \mathrm{~N}_{2}$ & & \\
\hline Test 1 & 100 & 502 & 75 & 45.4 & 9.1 & 45.5 & 5 & 1.10 \\
\hline Test 2 & 300 & 361 & 55 & 18.5 & 37 & 44.5 & 0.5 & 0.81 \\
\hline Test 4 & 100 & 1630 & 70 & 36.7 & 3.7 & 59.7 & 10 & 2.73 \\
\hline
\end{tabular}

(a) Assumes an atmospheric pressure of 850 mbar.

For Tests 1-3, weight gain measurements were taken at periodic intervals during the experiments. This was performed by ramping the furnace down to room temperature, removing and weighing the samples, reinserting the samples and ramping back to $850^{\circ} \mathrm{C}$ to continue the test. Samples were weighed at intervals of $0,20,50,100,200$, and 500 hours. Samples in Tests 4 and 5 were weighed only at the beginning and the end of the 500 hour test. An analytical balance with $0.1 \mathrm{mg}$ resolution was used for sample weight measurements. Initially a single weight measurement was made on each sample at each test interval. However, this method was discarded in exchange for performing 3 to 5 weight measurements on each sample to limit the experimental variability. The uncertainties in weight measurements are based on the 95\% confidence intervals (determined using the Student's $t$-test) from multiple measurements on each sample.

To determine surface-area-normalized weight gain measurements, the dimensions of each sample coupon were measured with calipers prior to each experiment. Surface areas used for these calculations were simply the geometric areas.

\subsection{Materials characterization}

After corrosion testing, samples were analyzed to evaluate corrosion scale morphology, thickness, and crystalline phase distribution. In addition, the resistivity of the surface scale layers was measured for the corroded samples as a function of temperature.

\subsubsection{GIXRD}

Grazing Incidence X-ray Diffraction (GIXRD) was used to characterize the crystalline phases in the corrosion scale on the tested materials. GIXRD uses a grazing incidence angle arrangement combined with a parallel beam geometry, as shown in Figure 3. By increasing the path length of the incident X-ray beam through the surface layer, the diffracted intensities from the coating or corrosion layer can be improved greatly, compared to the substrate and background. In our analysis, a conventional powder diffractometer (STOE) is converted to GIXRD by using the $2 \theta$ mode and a long Soller slit on the detector side. The signals are collected and analyzed using software STOE WinXPOW. GIXRD characterization was performed on the corroded samples and on the as-received coated samples for comparison. 


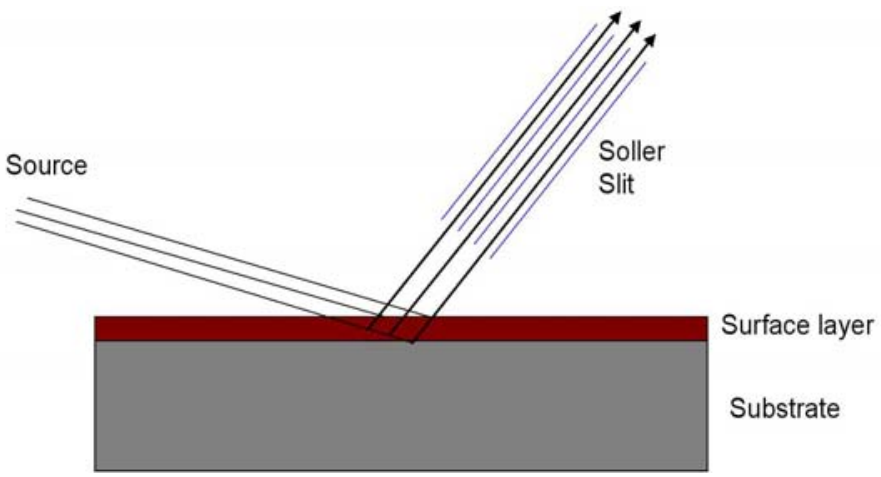

Figure 3. Geometry for GIXRD

\subsubsection{SEM}

The surfaces of corroded samples were analyzed with electron microscopy to evaluate the morphology oxide scales. Selected sample coupons were also cross-sectioned and analyzed with electron microscopy to measure surface scale thickness and evaluate layer morphologies. Energy dispersive spectroscopy was used to help identify elemental compositions of phases observed in the electron micrographs.

\subsubsection{ASR measurements}

Because of the requirement of good electrical conductivity on materials in multiple cell stacks, the area specific resistance of oxide layers on materials considered for interconnects or flow fields will be determined as a function of temperature after corrosion testing. This included the uncoated $\mathrm{NiCr}$ and FSS coupons, as well as the FSS coupons with Coating 1. Coatings 2 and 3 are considered for electrolysis cell stack edge rails, and therefore electrical resistivity is not a critical parameter.

These measurements were accomplished with a high temperature electrical test apparatus (Figure 4). Each test sample is placed within an electrically insulating ceramic holder with platinum electrodes on both sides. Platinum wire inside of the ceramic holders connects the electrodes to the outside of a simple clam-shell furnace for probe connection. The ceramic holders are spring tightened (not shown) to ensure good contact between electrodes and sample at all temperatures. Platinum paste (Engelhard, stock\# A4338) is applied to both faces of the sample to enhance electrical contact over the entire test temperature range.

PC4 cell cable probes (Gamry Instruments) connected the platinum wire to a potentiostat used in conjunction with Gamry Instruments software (FrameWork1 "DC105") to perform electrical resistive measurements at all temperatures. The potentiostat controls the voltage difference between the test sample electrodes (the working electrode) and an internal reference electrode allowing the current flow between the working and auxiliary electrodes to be monitored. Electrical resistance is derived from the applied voltage and measured current through the samples. A schematic of the measurement is shown in Figure 5.

The area specific resistance (ASR) of the oxide scale has the units of $\Omega \mathrm{cm}^{2}$ and is calculated using the following equation: 


$$
A S R=\left(\frac{R \cdot A}{2}\right)
$$

where $\mathrm{R}$ is the measured resistance $(\Omega)$ and $\mathrm{A}\left(\mathrm{cm}^{2}\right)$ is the electrical contact area between the $\mathrm{Pt}$ electrode and the sample. Dividing by 2 accounts for the fact the resistance measurement is performed across two oxide scale layers connected in series. The resistance of the alloy substrate and current leads are considered negligible compared to the resistance of the oxide scale.

With this system the electrical resistance can be measured at temperatures of up to $1000^{\circ} \mathrm{C}$.

The electrical resistance of each sample was tested perpendicular to the plane of the coating from room temperature to $1000^{\circ} \mathrm{C}$ and back to room temperature in $100^{\circ} \mathrm{C}$ increments. Several temperature cycles were performed to check the repeatability of the measurements. The sample temperature was allowed to stabilize before the electrical resistance was measured. A "Eurotherm" temperature controller was used to control the temperature of the furnace. A K-type thermocouple was inserted from the back of the furnace to monitor the temperature. All high temperature tests were conducted in a flowing argon cover gas to minimize corrosion of the samples during the measurement. Each sample was scanned at $10 \mathrm{mV} / \mathrm{s}$ voltage potential rate at a sample period of $0.1 \mathrm{sec}$. This was repeated every $24 \mathrm{sec}$ for a total time of $144 \mathrm{sec}$ yielding six distinct resistance data points at each temperature increment. The average value was calculated and recorded for each temperature increment.

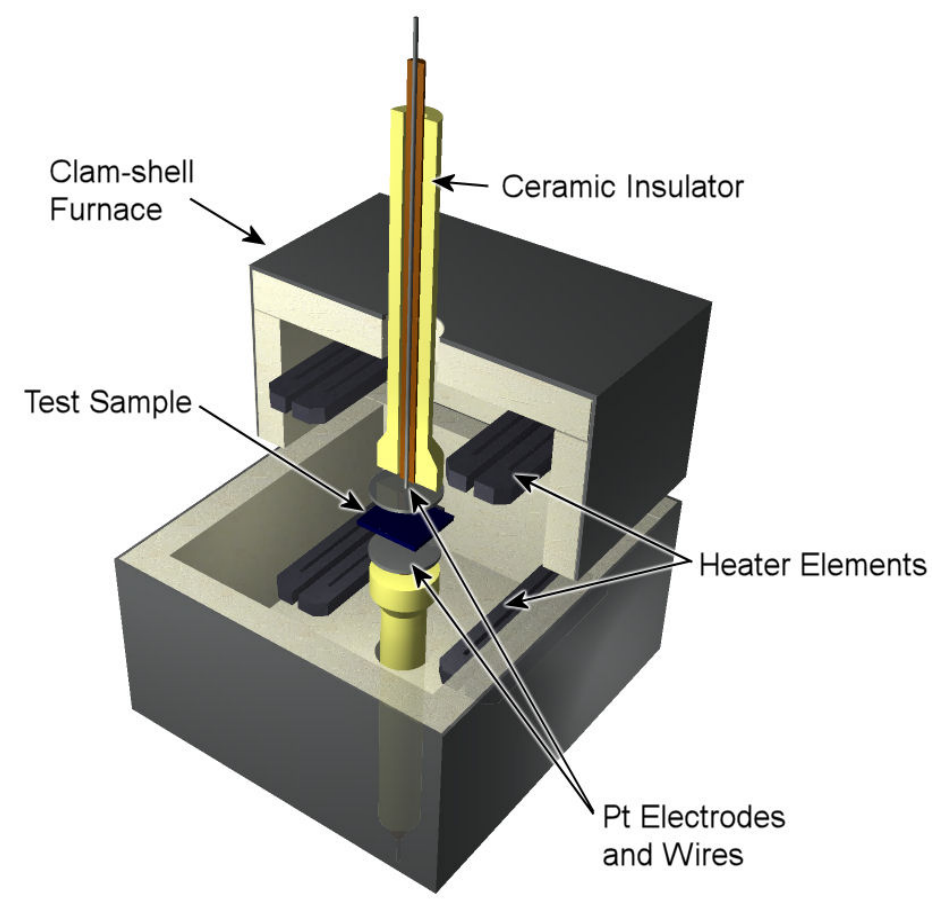

Figure 4. High temperature area specific resistivity measurement apparatus. 


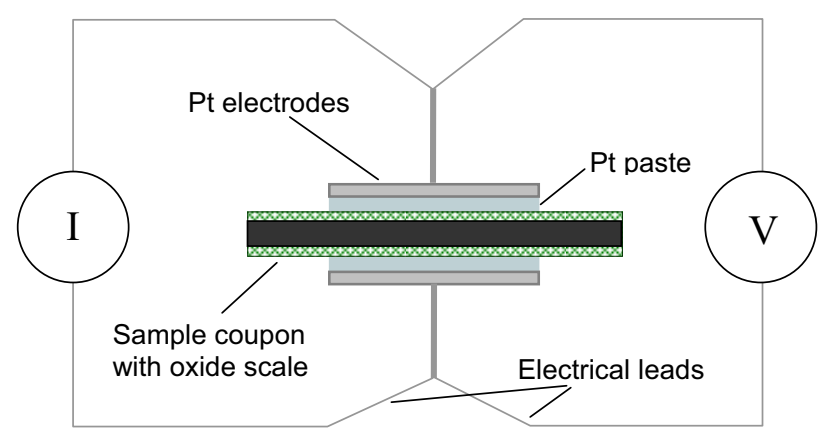

Figure 5. Schematic diagram of area specific resistivity meausurement.

\section{Results}

\subsection{System performance}

During the heating tests, the water bath exhibited a limited amount of variability, affecting the steam content of the $\mathrm{H}_{2} \mathrm{O} / \mathrm{H}_{2} / \mathrm{N}_{2}$ mixtures. The water bath temperature response during the $\mathrm{H}_{2} \mathrm{O} / \mathrm{H}_{2}$ tests is given in Table 4 . The data are averaged over each $\sim 500 \mathrm{~h}$ experiment (neglecting intervals where the tests were interrupted for sample weight measurements). The maximum variation in bath temperatures typically was on the order of $1.2-2.3^{\circ} \mathrm{C}$, neglecting very brief anomalous low temperature spikes.

The actual gas compositions realized during the $\mathrm{H}_{2} \mathrm{O} / \mathrm{H}_{2}$ tests are given in Table 5, including the $\mathrm{H}_{2} \mathrm{O} / \mathrm{H}_{2}$ ratios. The gas compositions were a function of the $\mathrm{H}_{2} / \mathrm{N}_{2}$ feed gas mixture and the water bath temperature. The uncertainty in $\mathrm{H}_{2} \mathrm{O} / \mathrm{H}_{2}$ ratios includes contributions from uncertainty in the water bath temperature, gas flow rates, and estimated average deviations in the ambient atmospheric pressure during a $500 \mathrm{~h}$ cycle (the average atmospheric pressure was assumed to be 850 mbar). For this report, these $\mathrm{H}_{2} \mathrm{O} / \mathrm{H}_{2}$ ratios are referred to in terms of the original target value, i.e. 0.5 , 5 , or 10 .

Table 4. Temperatures of the water bath for $500 \mathrm{~h}$ steam/hydrogen corrosion tests.

\begin{tabular}{|c|c|c|c|c|}
\hline Test \# & $\begin{array}{c}\text { Average } \\
\left({ }^{\circ} \mathbf{C}\right)\end{array}$ & Std. dev. & Max & Min \\
\hline Test 1 & 75.8 & 0.3 & 76.3 & $75.1^{(\mathrm{a})}$ \\
\hline Test 2 & 55.6 & 0.3 & 56.3 & $54.8^{(\mathrm{b})}$ \\
\hline Test 4 & 70.8 & 0.3 & 71.7 & $69.4^{(\mathrm{c})}$ \\
\hline
\end{tabular}

(a) There was one short $(<25 \mathrm{~min})$ excursion to $73.8^{\circ} \mathrm{C}$.

(b) There were two brief ( $<5 \mathrm{~min}$ ) excursions to $\sim 53.6^{\circ} \mathrm{C}$.

(c) There were two brief ( $<5 \mathrm{~min}$ ) excursions to $\sim 68.5^{\circ} \mathrm{C}$. 
Table 5. Actual experimental conditions for steam/hydrogen corrosion tests.

\begin{tabular}{|c|c|c|c|c|c|c|c|c|}
\hline \multirow{2}{*}{ Test \# } & \multicolumn{2}{|c|}{$\begin{array}{l}\text { Initial flow } \\
\text { (sccm) }\end{array}$} & \multirow{2}{*}{$\begin{array}{l}\text { Bath } \\
\text { temp. } \\
\left({ }^{\circ} \mathrm{C}\right)^{(\mathbf{a})}\end{array}$} & \multicolumn{3}{|c|}{ Final composition $^{(b)}$} & \multirow{2}{*}{$\mathbf{H}_{2} \mathbf{O} / \mathbf{H}_{2}^{\left({ }^{(c)}\right.}$} & \multirow{2}{*}{$\begin{array}{c}\text { Total } \\
\text { flow } \\
\text { (L/min) }\end{array}$} \\
\hline & $\mathrm{H}_{2}$ & $\mathbf{N}_{2}$ & & $\% \mathrm{H}_{2} \mathrm{O}$ & $\% \mathrm{H}_{2}$ & $\% \mathrm{~N}_{2}$ & & \\
\hline Test 1 & 100 & 500 & $75.8 \pm 0.6$ & 46.9 & 8.9 & 44.2 & $5.3 \pm 0.5$ & 1.13 \\
\hline Test 2 & 300 & 360 & $55.6 \pm 0.6$ & 19.1 & 36.8 & 44.2 & $0.52 \pm 0.04$ & 0.82 \\
\hline Test 4 & 100 & 1630 & $70.8 \pm 0.6$ & 38.0 & 3.6 & 58.5 & $10.6 \pm 0.9$ & 2.79 \\
\hline
\end{tabular}

(a) Uncertainty is based on two standard deviations $(2 \sigma)$.

(b) Assumes an atmospheric pressure of 850 mbar.

(c) Uncertainty includes contribution from uncertainty in bath temperature, flow rates, and ambient atmospheric pressure.

\subsection{Weight gain}

The end-of-test weight gain data for each of the five tests are given in Figure 6. The general procedure was to measure the weight gain from two the identical samples (when available) for each test and report the average. In certain cases, however, data from only one sample was used, either because only one set of samples was inserted in the furnace for a particular test or because a sample was damaged during the test in such a way that the weight was altered and no weight gain data could be collected. In addition, since early tests involved taking only a single weight reading for the initial measurement $(t=0)$ of each sample, the experimental uncertainty of these measurements had to be estimated based on the observed variation in later measurements. The estimated uncertainty in these cases was conservatively estimated as $\pm 0.0003 \mathrm{~g}$. Table 6 provides relevant notes on the weight gain measurement procedure for each of the tests. 


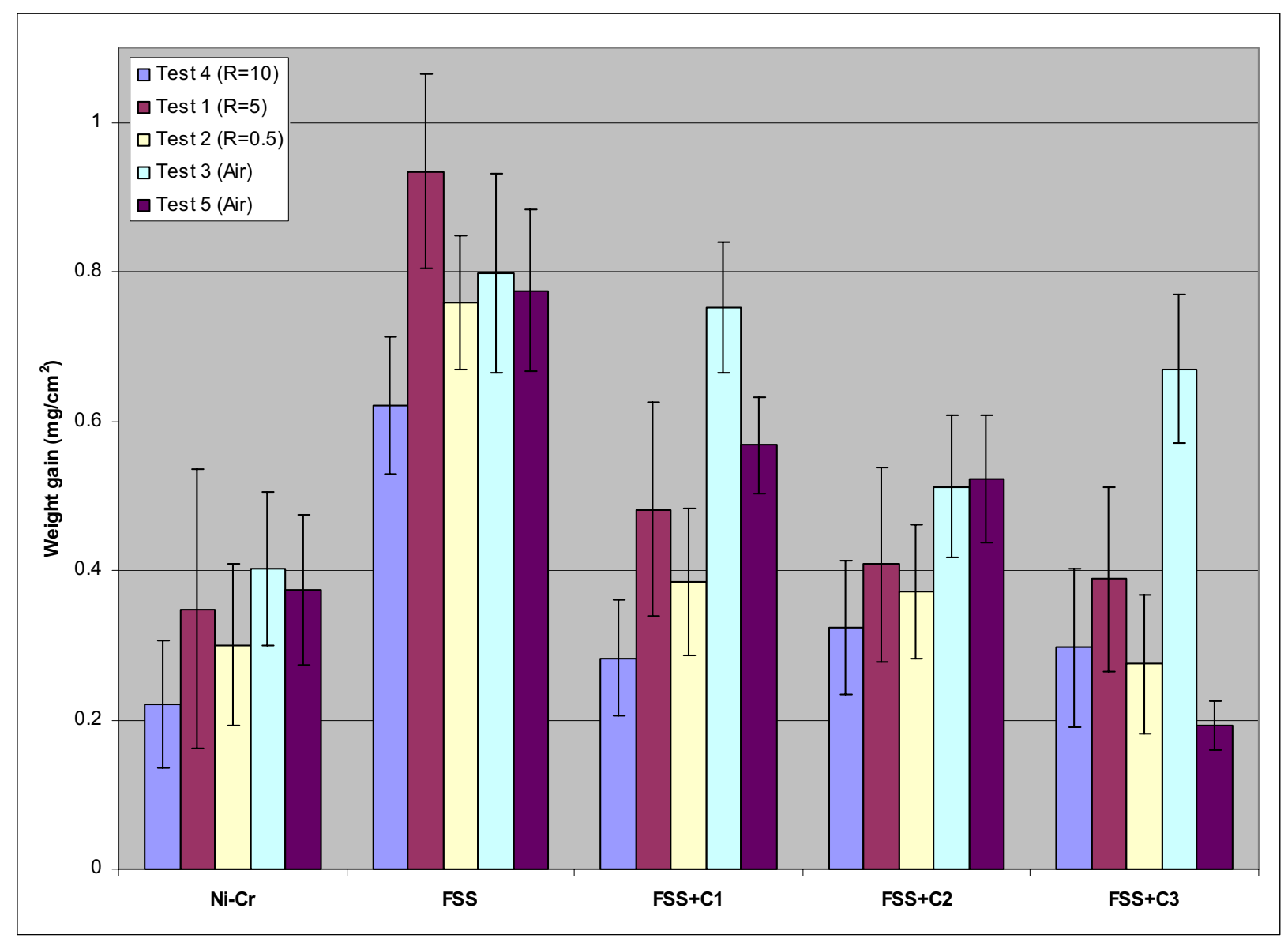

Figure 6. End of test weight gains from $500 \mathrm{~h}$ corrosion tests.

Table 6. Notes on the weight gain data from Phase I tests.

\begin{tabular}{|c|c|c|c|c|c|}
\hline Sample & $\begin{array}{l}\text { Test } 1 \\
(R=5)\end{array}$ & $\begin{array}{c}\text { Test } 2 \\
(R=0.5)\end{array}$ & $\begin{array}{c}\text { Test } 3 \\
\text { (Air) }\end{array}$ & $\begin{array}{c}\text { Test } 4 \\
(R=10)\end{array}$ & $\begin{array}{l}\text { Test } 5 \\
\text { (Air) }\end{array}$ \\
\hline $\mathrm{NiCr}$ & $(\mathrm{a}, \mathrm{b})$ & (b) & (b) & & (a) \\
\hline FSS & $(\mathrm{a}, \mathrm{b})$ & (b) & $(\mathrm{a}, \mathrm{b})$ & & (a) \\
\hline FSS + Coating 1 & $(\mathrm{a}, \mathrm{b})$ & (b) & (b) & & (d) \\
\hline FSS + Coating 2 & $(\mathrm{a}, \mathrm{b})$ & (b) & (b) & & $(\mathrm{a}, \mathrm{c})$ \\
\hline FSS + Coating 3 & $(\mathrm{a}, \mathrm{b})$ & (b) & (b) & $(\mathrm{a}, \mathrm{c})$ & (d) \\
\hline \multicolumn{6}{|c|}{ (a) Weight gain data is based on measurement of only one sample } \\
\hline \multicolumn{6}{|c|}{$\begin{array}{l}\text { (b) Uncertainty in measurement of initial weight was not determined } \\
\text { experimentally (only one measurement of weight was made), so this was } \\
\text { estimated to be } \pm 0.0003 \mathrm{~g} \text { based on observed performance of the analytical } \\
\text { balance in Bay } 9 \text {. }\end{array}$} \\
\hline \multicolumn{6}{|c|}{$\begin{array}{l}\text { (c) The weight gain values from the two measured samples were significantly } \\
\text { different, apparently because they were from different coating lots. As a result, } \\
\text { only the data from the sample belonging to the } 1^{\text {st }} \text { lot is included. }\end{array}$} \\
\hline \multicolumn{6}{|c|}{ (d) Both tested samples were from the $2^{\text {nd }}$ coating batch. } \\
\hline
\end{tabular}

The following trends can be observed in the $500 \mathrm{~h}$ weight gain data in Figure 6: 
1. FSS vs. NiCR. In all test atmospheres the weight gain of the uncoated FSS material was higher than NiCr.

2. Effect of $\mathrm{H}_{2}{\underline{\mathrm{O}} / \mathrm{H}_{2}}_{2}$ ratio. With only one exception, the particular $\mathrm{H}_{2} \mathrm{O} / \mathrm{H}_{2}$ ratio of the gas (Tests 1, 2, and 4) had no effect on the weight gains of any of the samples. The exception was the uncoated FSS; in this case the weight gain of the FSS samples heated in an $\mathrm{H}_{2} \mathrm{O} / \mathrm{H}_{2}$ ratio of 10 were lower than those with a ratio of 5 . It is not known if the nature of Test $4\left(\mathrm{H}_{2} \mathrm{O} / \mathrm{H}_{2}=10\right)$, which was run without periodic interruptions for sample weight measurements, influenced the final weight gain to give lower values. As will be discussed shortly, a comparison of Test 3 and Test 5 data suggest that this is not the case.

3. Comparison of interrupted (Test 3) vs. uninterrupted (Test 5) air tests. The two different air tests (Tests 3 and 5) resulted in the same weight gains for NiCr, uncoated FSS, and FSS with Coating 2. This indicates that eliminating the periodic interruptions in Test 5 apparently did not influence sample weight gain. While it may appear that the Test 3 and 5 results for the samples with coatings 1 and 3 contradict this assessment, this observation can be explained by the fact that both of the sample coupons of these materials in Test 5 were taken from the second lot of samples sent from Ceramatec (see discussion in Section 2.2). The fact that these materials both show lower corrosion rates in Test 5, while the remaining materials (all from Lot 1) showed the same corrosion rates in Tests 3 and 5 suggest that there was a variation in the coating properties between the two lots which significantly influenced corrosion behavior. Thus the weight gain data from Test 5 for FSS with coatings 1 and 3 are not considered to be directly comparable with the rest of the data in Figure 6.

4. Variation in performance of coatings from different lots. The variation of corrosion behavior between the two lots of samples was further confirmed by two pairs of samples from Test 4 (FSS + Coating 3 specimens) and Test 5 (FSS + Coating 2 specimens). In both of these tests, one of the sample coupons was from Lot 1 and the other from Lot 2, and in both cases the sample coupons from Lot 2 exhibited significantly lower weight gain at the end of the test. (In both of these instances, only the data from the Lot 1 sample was used in Figure 6; see note (c) in Table 6). Figure 7 shows the comparisons for clarity, and clearly demonstrates the improved corrosion behavior of coatings from Lot 2. In all other instances where two identical samples from the same lot were heated in a particular experiment, the weight gains of the two samples were the same within the experimental uncertainty. Thus the data consistently show lower weight gains for coated samples from Lot 2. Because very few of the samples from Lot 2 were used in these experiments, the comparisons of coating performance are made on the data from Lot 1 samples for consistency.

5. Coating performance in air and $\mathrm{H}_{2} \underline{\mathrm{O}}_{2} \mathrm{H}_{2}$. The coated FSS samples exhibited a greater reduction in corrosion rate compared to the uncoated material in $\mathrm{H}_{2} \mathrm{O} / \mathrm{H}_{2}$ atmospheres than they did in air. Air corrosion rates for the FSS samples with Coating 1 and 3 in fact showed no statistical difference from those of the uncoated steel. Only the samples with Coating 2 exhibited lower corrosion rates in air than the uncoated steel (this analysis disregards the data for samples from Lot 2, as discussed above). 
By contrast, the reduction in corrosion rates of the coated materials in $\mathrm{H}_{2} \mathrm{O} / \mathrm{H}_{2}$ was much more significant. The average weight gains of the coated steels were decreased by a factor of at least 50\% compared to the uncoated steel tested in the same atmosphere. However, none of the coatings performed significantly better than the others, with the weight gains for all three of the coated materials in all three $\mathrm{H}_{2} \mathrm{O} / \mathrm{H}_{2}$ atmospheres being the same within experimental uncertainty.

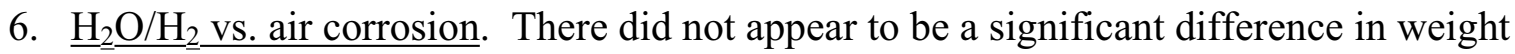
gain for the uncoated specimens ( $\mathrm{NiCr}$ and FSS) in air compared to $\mathrm{H}_{2} \mathrm{O} / \mathrm{H}_{2}$ mixtures. However, as noted above, corrosion of FSS with Coating 1 and 3 was higher in air than in $\mathrm{H}_{2} \mathrm{O} / \mathrm{H}_{2}$. For Coating 2, there is only a very slight decrease in weight gains for samples heated in $\mathrm{H}_{2} \mathrm{O} / \mathrm{H}_{2}$ compared to those heated in air.

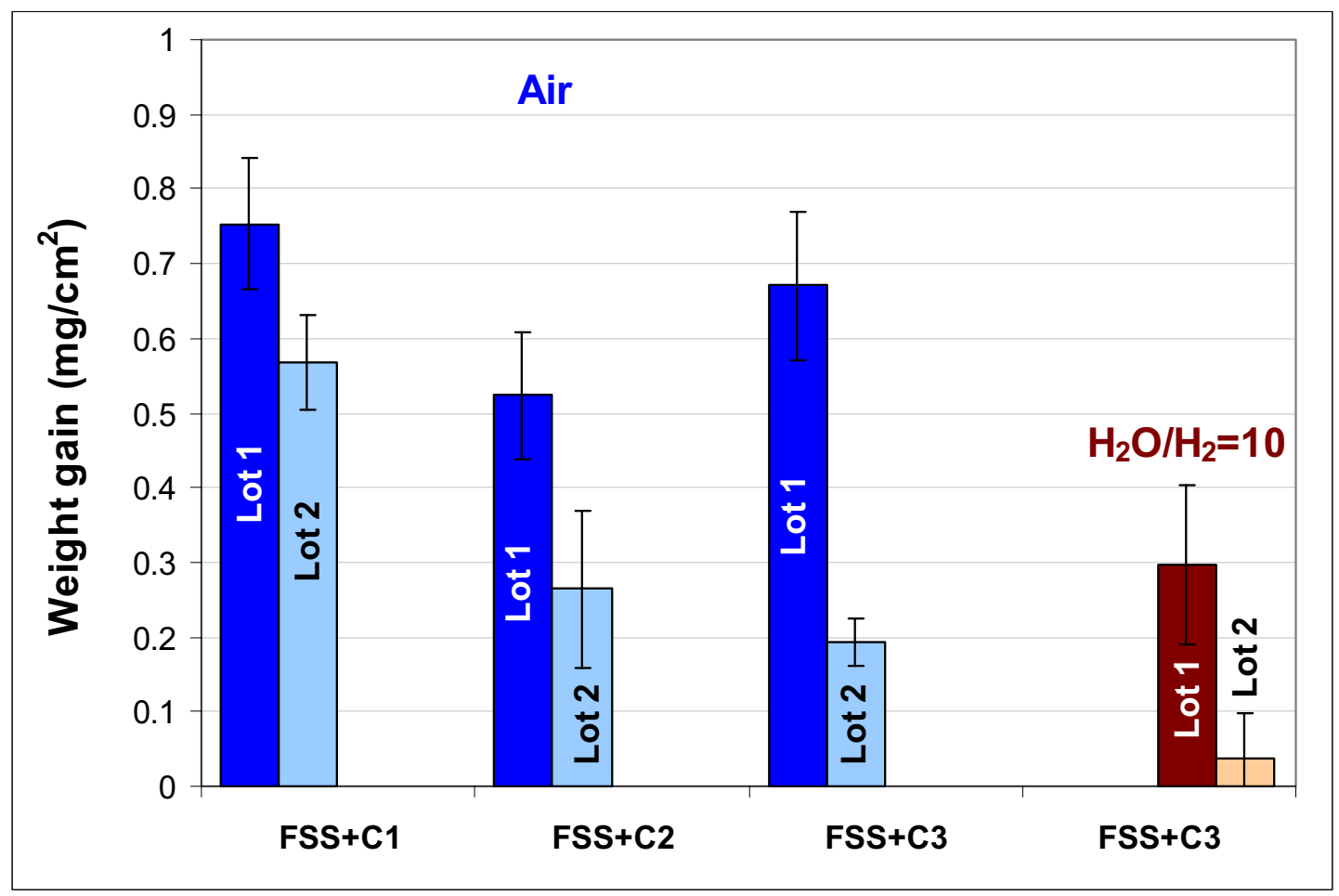

Figure 7. Weight gain data for coated FSS samples from two different coating lots. Air corrosion data are shown on the left, $\mathrm{H}_{2} \mathrm{O} / \mathrm{H}_{2}$ corrosion data are shown on the right. The coating lot and the corrosion test number are given for each data point.

The weight gain data for the 440C specimens from Test 1 are shown in Figure 8 as a function of time for comparison. The data indicate that the corrosion behavior of the three coatings on 440C steel are similar, and that the overall weight gains are much higher than for the FSS or NiCr specimens by a factor of at least 30 . The lack of difference in weight change between coupons with the three different coatings is consistent with the data for the FSS specimens corroded in $\mathrm{H}_{2} \mathrm{O} / \mathrm{H}_{2}$ mixtures, shown in Figure 6. Because of the relatively poor performance of the $440 \mathrm{C}$ 
samples relative to the higher chromium FSS material, these specimens have not been characterized further. $440 \mathrm{C}$ had been used for the manifolds only because the desired thickness of 446 was not available.

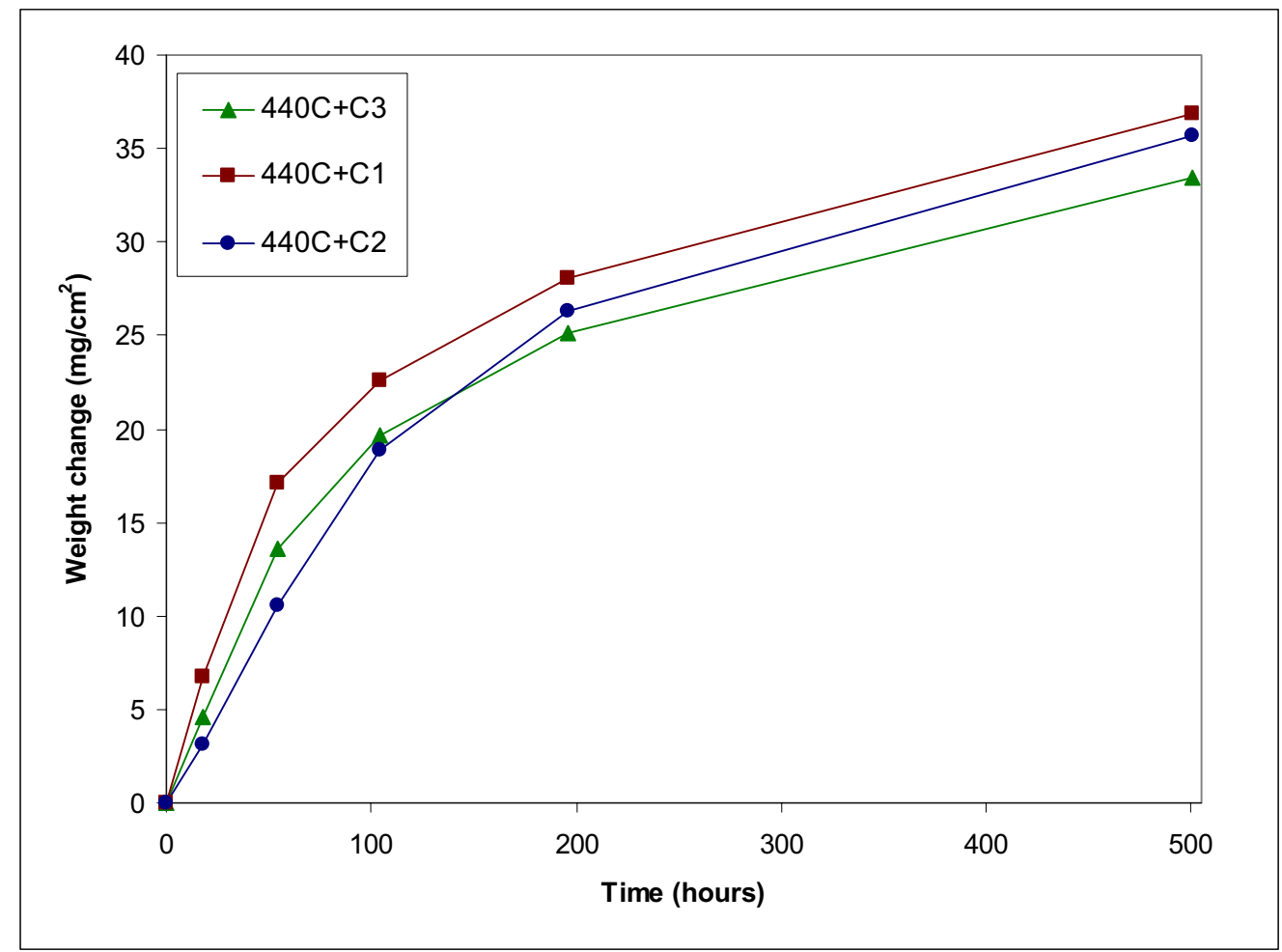

Figure 8. Weight gain data for coated $440 \mathrm{C}$ stainless steel specimens from Test $1\left(\mathrm{H}_{2} \mathrm{O} / \mathrm{H}_{2}=5\right)$. Test temperature was $850^{\circ} \mathrm{C}$.

\subsubsection{Reaction kinetics}

The kinetics of the corrosion reactions were considered by analyzing the time-dependent weight gain data. In the case of Tests 4 and $5\left(\mathrm{H}_{2} \mathrm{O} / \mathrm{H}_{2}=10\right.$ and air, respectively), no intermediate weight measurements were made, so no time dependent data are available. For Test 1, the use of only a single coupon for each material and the lack of statistical averaging of the weight data resulted in a great deal of scatter, and conclusions were difficult to draw. This leaves the time-dependent weight gain data for Tests 2 and $3\left(\mathrm{H}_{2} \mathrm{O} / \mathrm{H}_{2}=0.5\right.$ and air, respectively). The weight gains as a function of time for Tests 2 and 3 are shown in Figure 9 and Figure 10.

Parabolic reaction kinetics are often observed for oxidation of metals, following the relationship

$$
\Delta m^{2}=k_{p} t
$$

Eq. 3

where $k_{\mathrm{p}}$ is the parabolic rate constant.

The data for Tests 2 and 3 were plotted as the square of the weight gain $\left(\Delta m^{2}\right)$ vs. time. Data that follows a parabolic relationship will be linear with a slope equal to $k_{\mathrm{p}}$. Data that deviates 
from linear behavior exhibits non-parabolic reaction kinetics. Figure 11 shows an example of both kinds of behavior. The parabolic rate constant, $k_{\mathrm{p}}$, for materials exhibiting non-parabolic behavior is not constant, and is equal to the instantaneous slope of the curve. The data were fit with either linear $(\mathrm{y}=a+b \mathrm{x})$ or 2-parameter power $\left(\mathrm{y}=a \mathrm{x}^{b}\right)$ functions. The slopes of these curves give the parabolic rate constant. These data are presented in Table 7 . The only exception to these two forms is the FSS+Coating 3 sample heated in $\mathrm{H}_{2} \mathrm{O} / \mathrm{H}_{2}$ (Test 2), which exhibited linear reaction behavior.

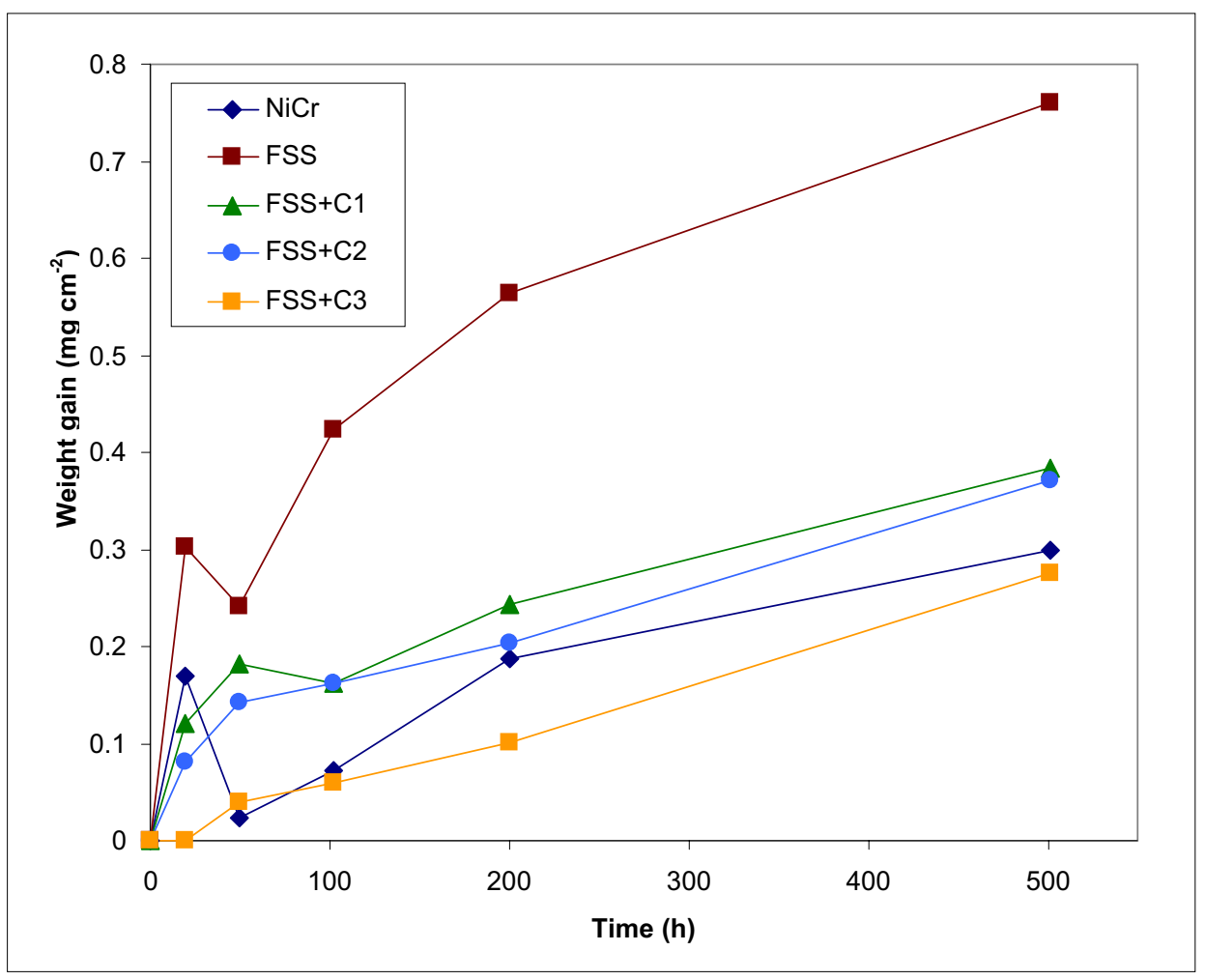

Figure 9. Weight gain at $850^{\circ} \mathrm{C}$ in steam-hydrogen $\left(\mathrm{H}_{2} \mathrm{O} / \mathrm{H}_{2}=0.5\right)$. 


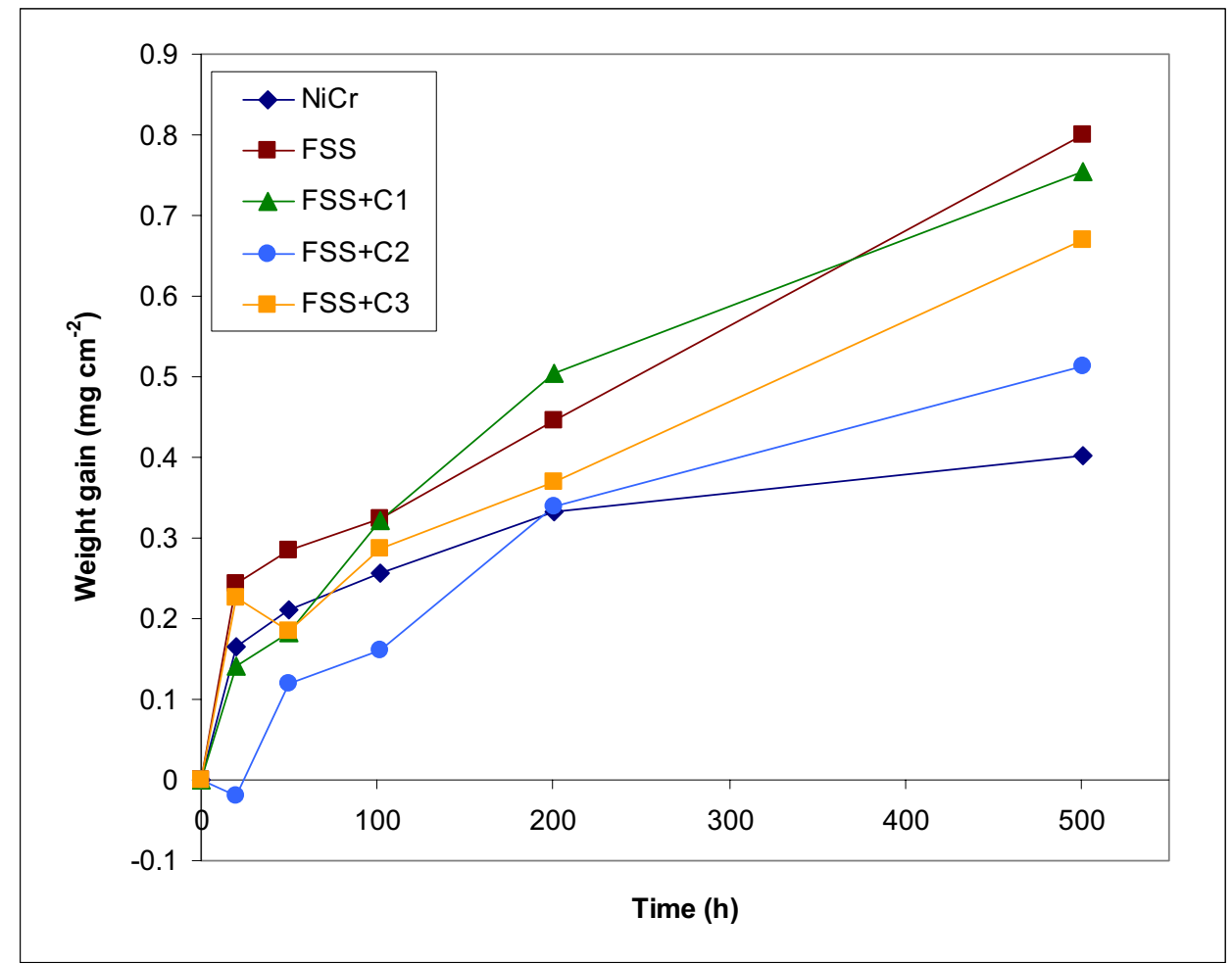

Figure 10. Weight gain at $850^{\circ} \mathrm{C}$ in dry air.

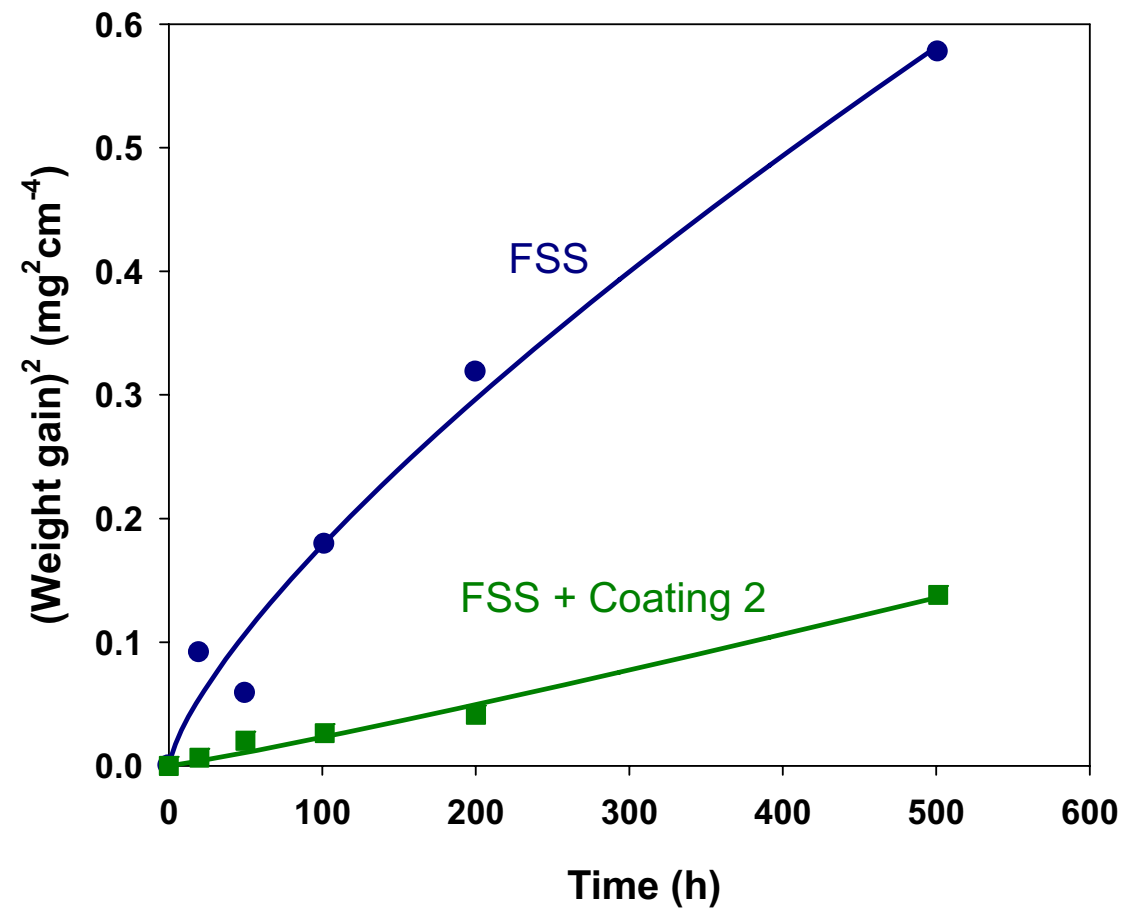

Figure 11. Weight gain data from Test $2\left(\mathrm{H}_{2} \mathrm{O} / \mathrm{H}_{2}=0.5\right)$ for uncoated FSS and FSS+Coating 2 specimens. 
Table 7. Parabolic rate constants for oxidation in $\mathrm{H}_{2} \mathrm{O} / \mathrm{H}_{2}$ (Test 2) and dry air (Test 3) at $850^{\circ} \mathrm{C}$

\begin{tabular}{|l|l|c|l|c|}
\hline \multirow{2}{*}{ Material } & \multicolumn{2}{|c|}{ Test 2 $\left(\mathbf{H}_{\mathbf{2}} \mathbf{O} / \mathbf{H}_{\mathbf{2}}=\mathbf{0 . 5}\right)$} & \multicolumn{2}{c|}{ Test 3 (Air) } \\
\cline { 2 - 5 } & Kinetics & $\boldsymbol{k}_{\mathrm{p}}\left(\mathbf{g}^{2} \mathbf{c m}^{-4} \mathbf{s}^{-1}\right)$ & Kinetics & $\boldsymbol{k}_{\mathbf{p}}\left(\mathbf{g}^{2} \mathbf{c m}^{-4} \mathbf{s}^{-1}\right)$ \\
\hline $\mathrm{NiCr}$ & Parabolic & $4.7 \times 10^{-14}$ & Non-parabolic & $0.49-2.2 \times 10^{-13}$ \\
\hline FSS & Non-parabolic & $2.4-5.6 \times 10^{-13}$ & Parabolic & $3.4 \times 10^{-13}$ \\
\hline FSS + Coating 1 & Parabolic & $7.8 \times 10^{-14}$ & Parabolic & $3.2 \times 10^{-13}$ \\
\hline FSS + Coating 2 & Parabolic & $7.4 \times 10^{-14}$ & Parabolic & $1.5 \times 10^{-13}$ \\
\hline FSS + Coating 3 & Linear & -- & Parabolic & $2.4 \times 10^{-13}$ \\
\hline
\end{tabular}

It is not clear why the NiCr material exhibited parabolic behavior for Test 2 and non-parabolic behavior for Test 3, and why the uncoated FSS was the opposite. It should be noted, however, that the temperature of these tests $\left(850^{\circ} \mathrm{C}\right)$ is near the temperature at which reaction kinetics for nickel-based alloys and stainless steels transition from parabolic to non-parabolic behavior. ${ }^{9}$

\subsection{Corrosion microstructures}

\subsubsection{As-received samples}

The surface microstructures of the as-received coated samples are shown in Figure 12-Figure 14 for comparison with the corroded samples. The FSS + Coating 3 specimen exhibits two distinct types of surface morphology, one containing acicular, fibrous particles and the other exhibiting a more granular microstructure. Both are shown in Figure 14. It can be seen that the top layer of specimens with Coating 1 and Coating 2 are quite porous.

Grazing incidence x-ray diffraction patterns of the FSS specimens with Coating 1 and Coating 3 are shown in Figure 15. Both sample surfaces contain $\mathrm{Cr}_{2} \mathrm{O}_{3}, \mathrm{MnCr}_{2} \mathrm{O}_{4}$ and $(\mathrm{RE}) \mathrm{CrO}_{3}$ phases (where "RE" indicates a rare earth element).
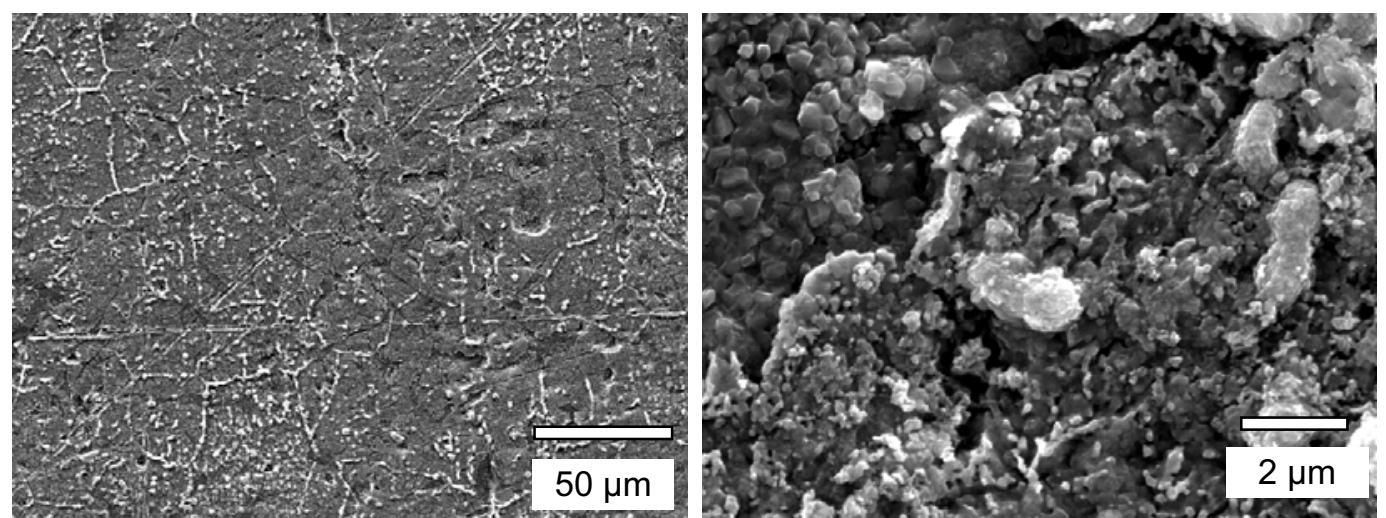

Figure 12. Surface microstructure of FSS + Coating 1 sample. 

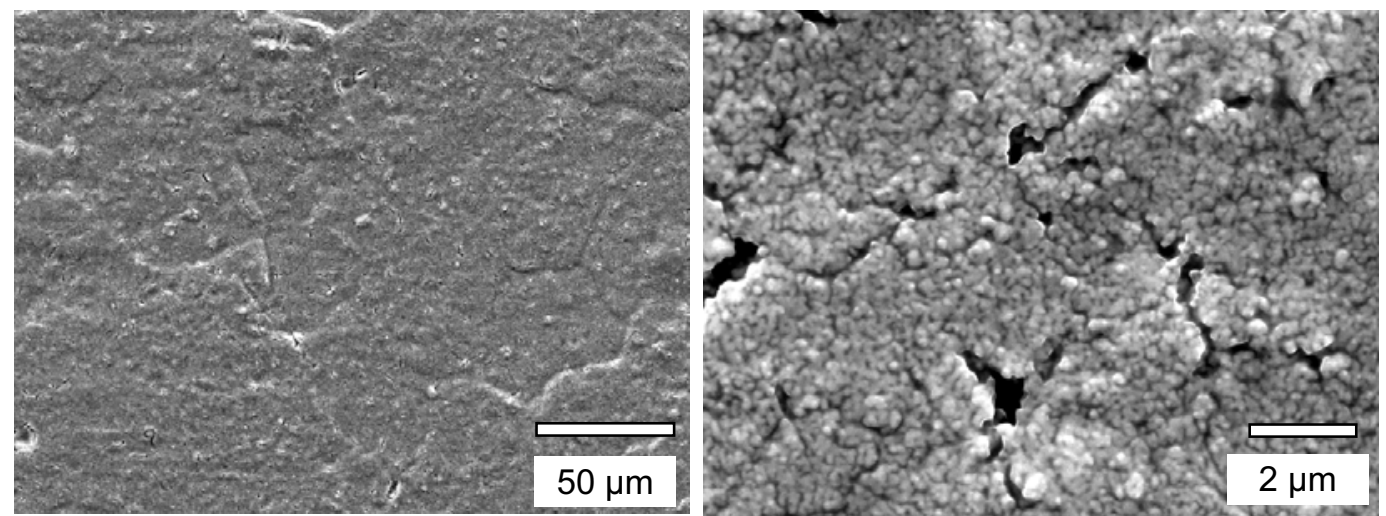

Figure 13. Surface microstructure of FSS + Coating 2 sample.
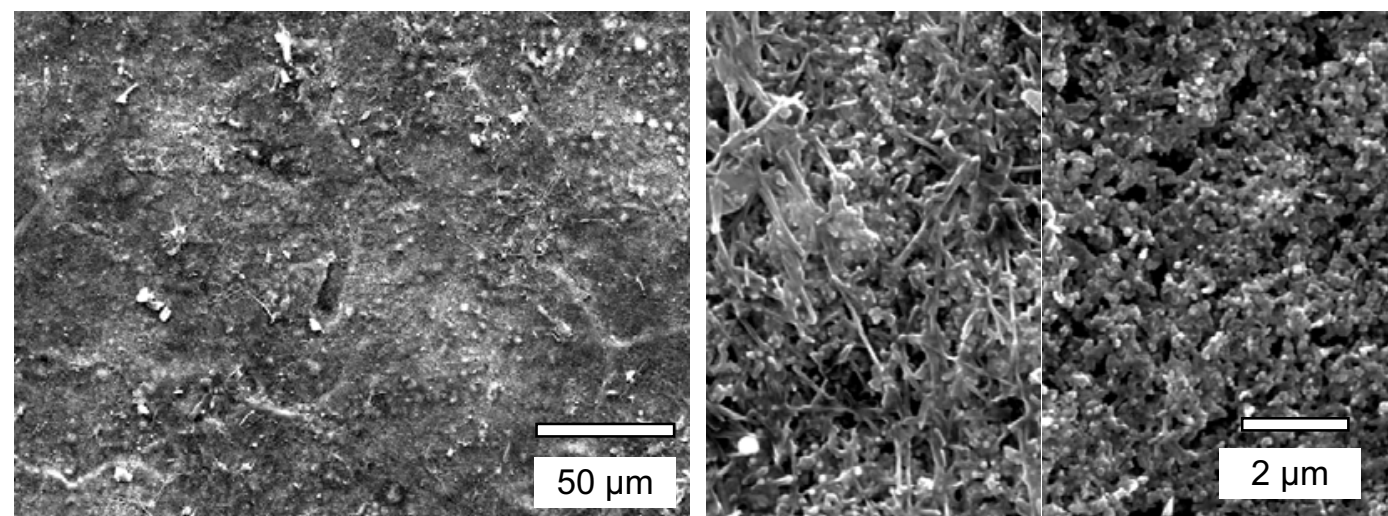

Figure 14. Surface microstructure of FSS + Coating 3 sample. Two different types of surface morphology are shown in the magnified images on the right.
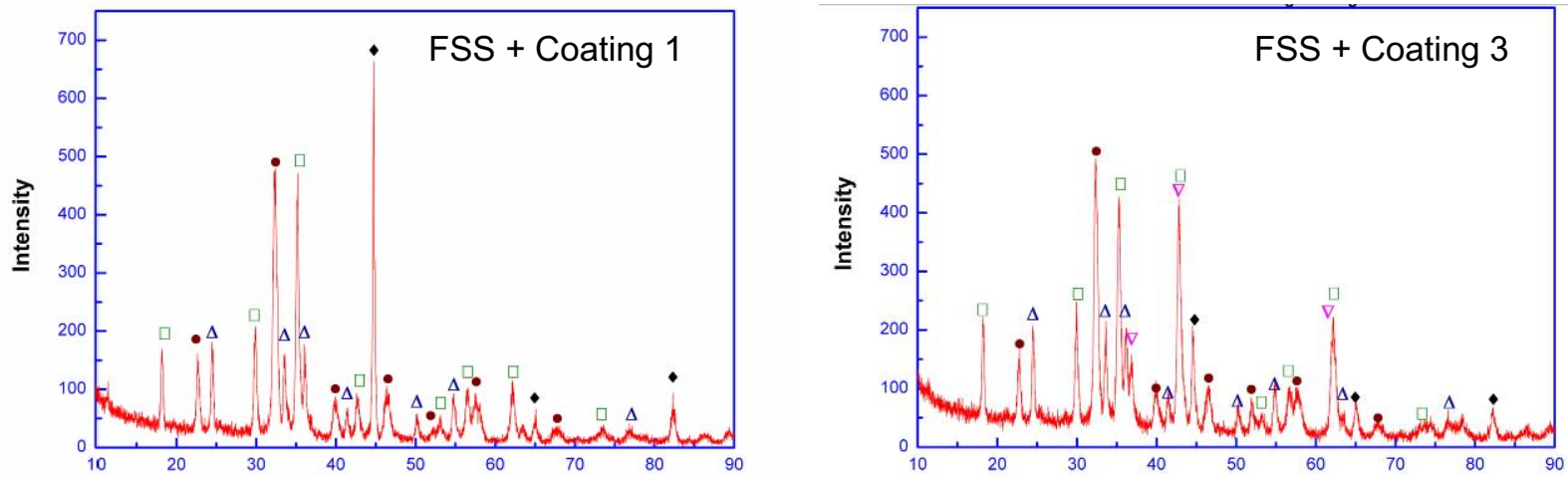

Figure 15. Grazing incidence $x-$ ray diffraction patterns of as-received samples FSS + Coating 1 (left) and FSS + Coating 3 (right).

\subsubsection{Steam/hydrogen corrosion}

Scanning electron micrographs of corroded sample surfaces are shown in Figure 16-Figure 20. Cross-sectional micrographs of the FSS + Coating 3 and FSS + Coating 2 samples from Test 2 $\left(\mathrm{H}_{2} \mathrm{O} / \mathrm{H}_{2}=0.5\right)$ are shown in Figure 21. Grazing incidence $\mathrm{x}$-ray diffraction patterns from each of 
the samples from Test $1\left(\mathrm{H}_{2} \mathrm{O} / \mathrm{H}_{2}=5\right)$ are shown in Figure 22. Table 8 summarizes the crystalline phases identified on the surfaces of the corroded samples, based on GIXRD data.

The surfaces of the uncoated FSS and FSS + Coating 1 specimens are similar in appearance, and the XRD data indicate the same phases. Note that there were no rare-earth element oxide phases detected on any of the coated steel specimens after $\mathrm{H}_{2} \mathrm{O} / \mathrm{H}_{2}$ corrosion, in contrast to the asreceived specimens (Figure 15). It is not yet known if this is due to a reaction that consumed this layer during testing, or if the thicker oxide layers that grew during corrosion have covered the ( $\mathrm{RE}) \mathrm{CrO}_{3}$ layer that was originally present, making it undetectable to the low angle $\mathrm{x}$-rays, which have a relatively shallow depth of penetration. Standard $\Theta-2 \Theta x$-ray diffraction patterns will be obtained on these samples to determine if there are any sub-surface phases that have been missed by the GIXRD analysis.

The surface of the FSS + Coating 2 specimen appears similar to the as-received specimen (Figure 13). The cross-sections of the FSS specimens with Coating 2 and Coating 3 (Figure 21) indicate that the oxide layers developed during corrosion have grown immediately adjacent to the substrate metal, underneath the porous ceramic oxide phase that is part of the coating. It is noted that, unlike the FSS specimens with Coating 1 and Coating 3, no $\mathrm{Cr}_{2} \mathrm{O}_{3}$ phase is observed on the FSS + Coating 2 sample. The oxide scale thicknesses for these two samples estimated from the SEM micrographs are $3.2 \mu \mathrm{m}( \pm 1.1)$ for FSS + Coating 2 and $2.3 \mu \mathrm{m}( \pm 0.4)$ for FSS + Coating 3. This does not include the thickness of the porous oxide layer that was part of the original coating.
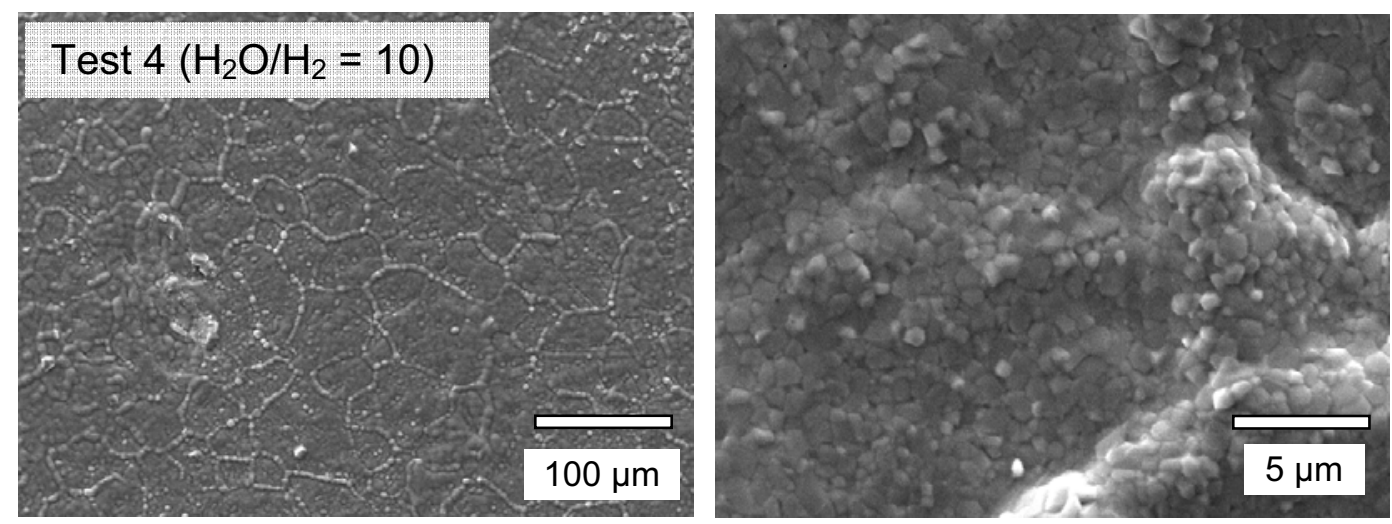

Figure 16. Surface micrographs of uncoated FSS exposed to a $\mathrm{H}_{2} \mathrm{O} / \mathrm{H}_{2} / \mathrm{N}_{2}$ mixture $\left(\mathrm{H}_{2} \mathrm{O} / \mathrm{H}_{2}=10\right)$ at $850^{\circ} \mathrm{C}$ for $500 \mathrm{~h}$ (Test 4$)$. 

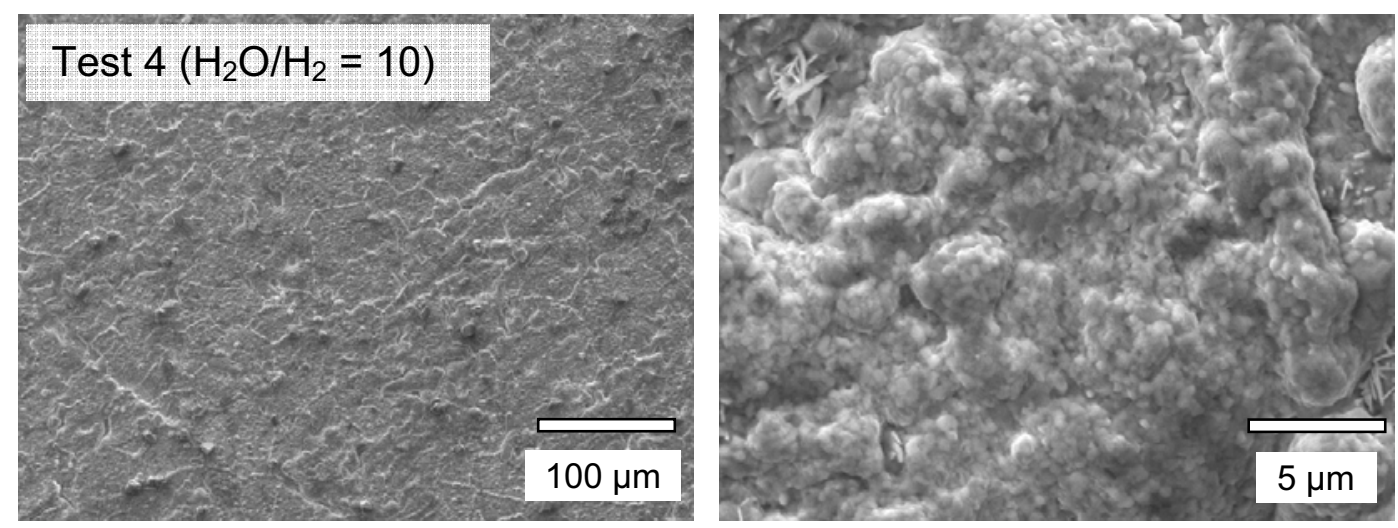

Figure 17. Surface micrographs of FSS + Coating 1 exposed to a $\mathrm{H}_{2} \mathrm{O} / \mathrm{H}_{2} / \mathrm{N}_{2}$ mixture $\left(\mathrm{H}_{2} \mathrm{O} / \mathrm{H}_{2}=10\right)$ at $850^{\circ} \mathrm{C}$ for $500 \mathrm{~h}$ (Test 4$)$.
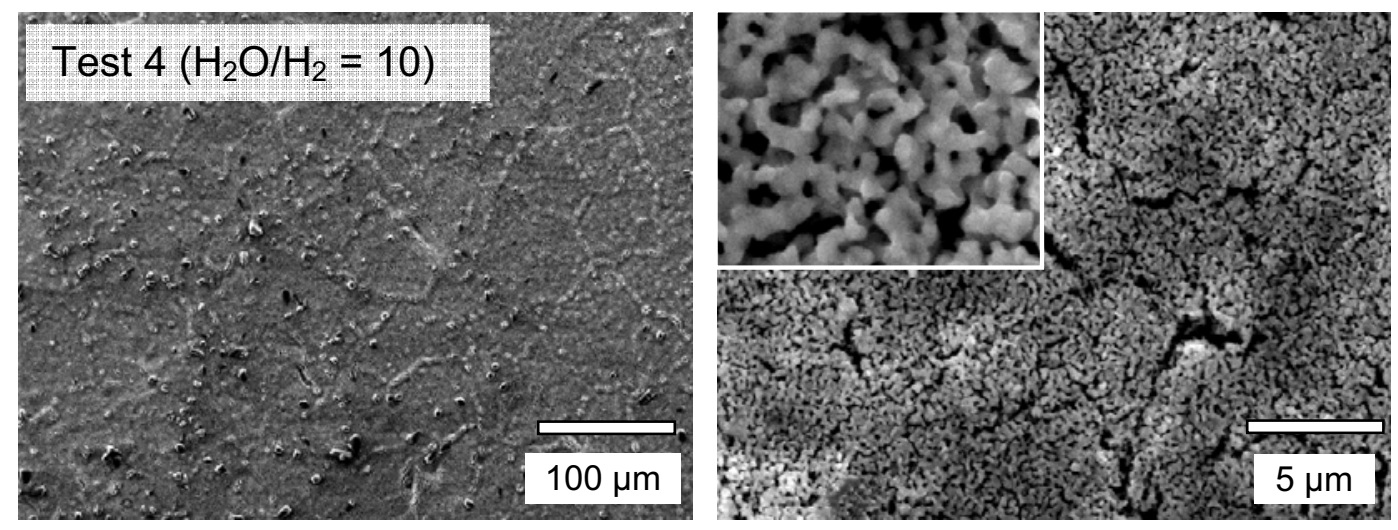

Figure 18. Surface micrographs of FSS + Coating 2 exposed to a $\mathrm{H}_{2} \mathrm{O} / \mathrm{H}_{2} / \mathrm{N}_{2}$ mixture $\left(\mathrm{H}_{2} \mathrm{O} / \mathrm{H}_{2}=10\right)$ at $850^{\circ} \mathrm{C}$ for $500 \mathrm{~h}$ (Test 4).
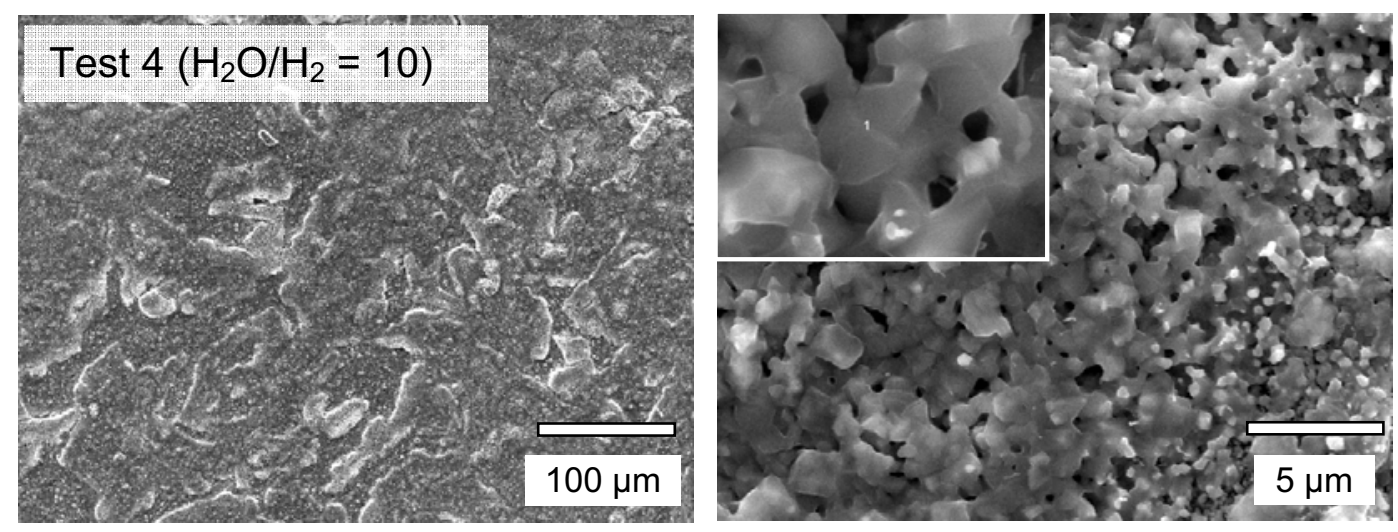

Figure 19. Surface micrographs of FSS + Coating 3 exposed to a $\mathrm{H}_{2} \mathrm{O} / \mathrm{H}_{2} / \mathrm{N}_{2}$ mixture $\left(\mathrm{H}_{2} \mathrm{O} / \mathrm{H}_{2}=10\right)$ at $850^{\circ} \mathrm{C}$ for $500 \mathrm{~h}$ (Test 4$)$. 

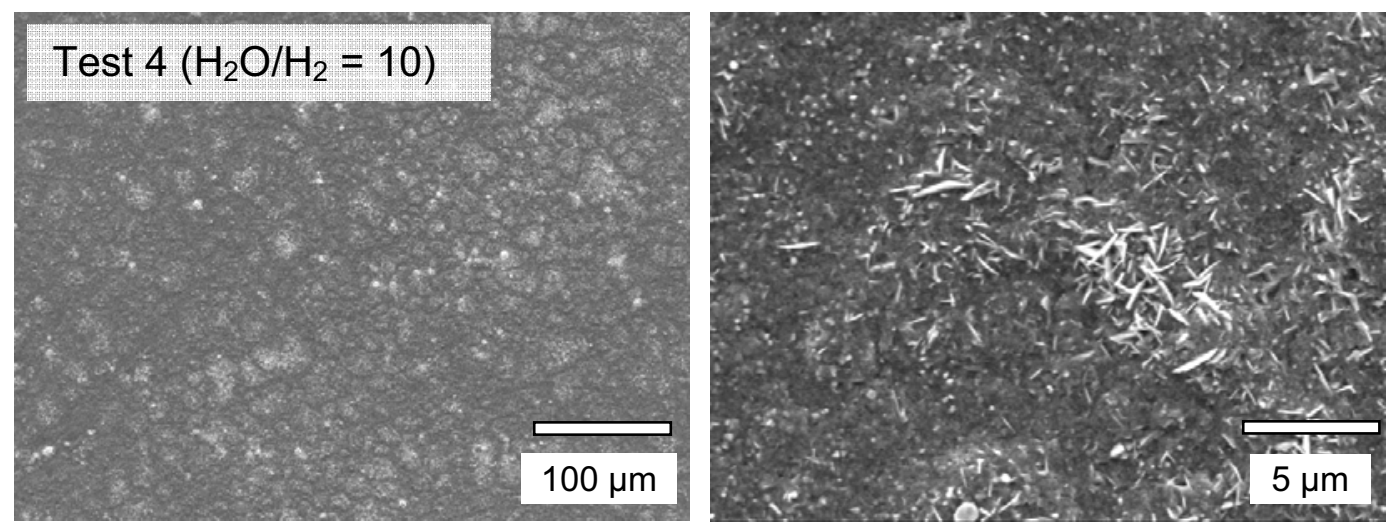

Figure 20. Surface micrographs of uncoated $\mathrm{NiCr}$ exposed to a $\mathrm{H}_{2} \mathrm{O} / \mathrm{H}_{2} / \mathrm{N}_{2}$ mixture $\left(\mathrm{H}_{2} \mathrm{O} / \mathrm{H}_{2}=10\right)$ at $850^{\circ} \mathrm{C}$ for $500 \mathrm{~h}$ (Test 4 ).
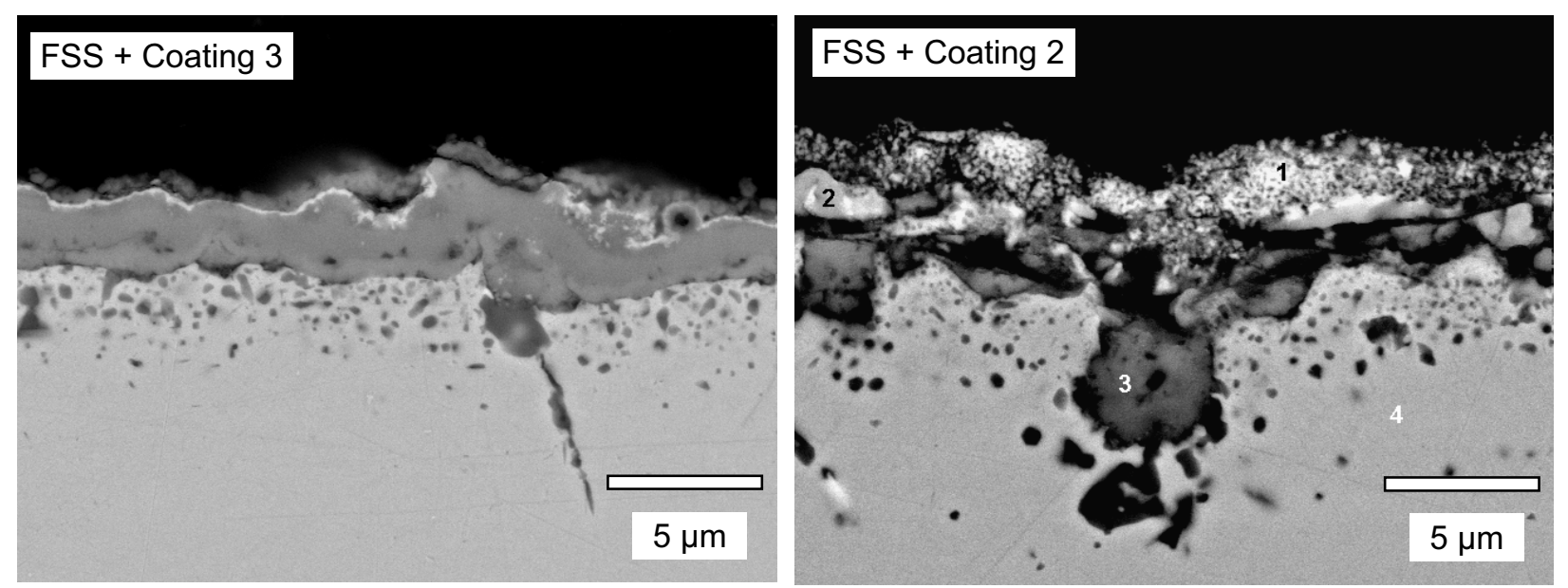

Figure 21. Cross-sectional micrographs of coated FSS specimens exposed to an $\mathrm{H}=\mathrm{O} / \mathrm{H}_{2} / \mathrm{N}_{2}$ mixture $\left(\mathrm{H}_{2} \mathrm{O} / \mathrm{H}_{2}=0.5\right)$ at $850^{\circ} \mathrm{C}$ for $500 \mathrm{~h}$ (Test 2). 

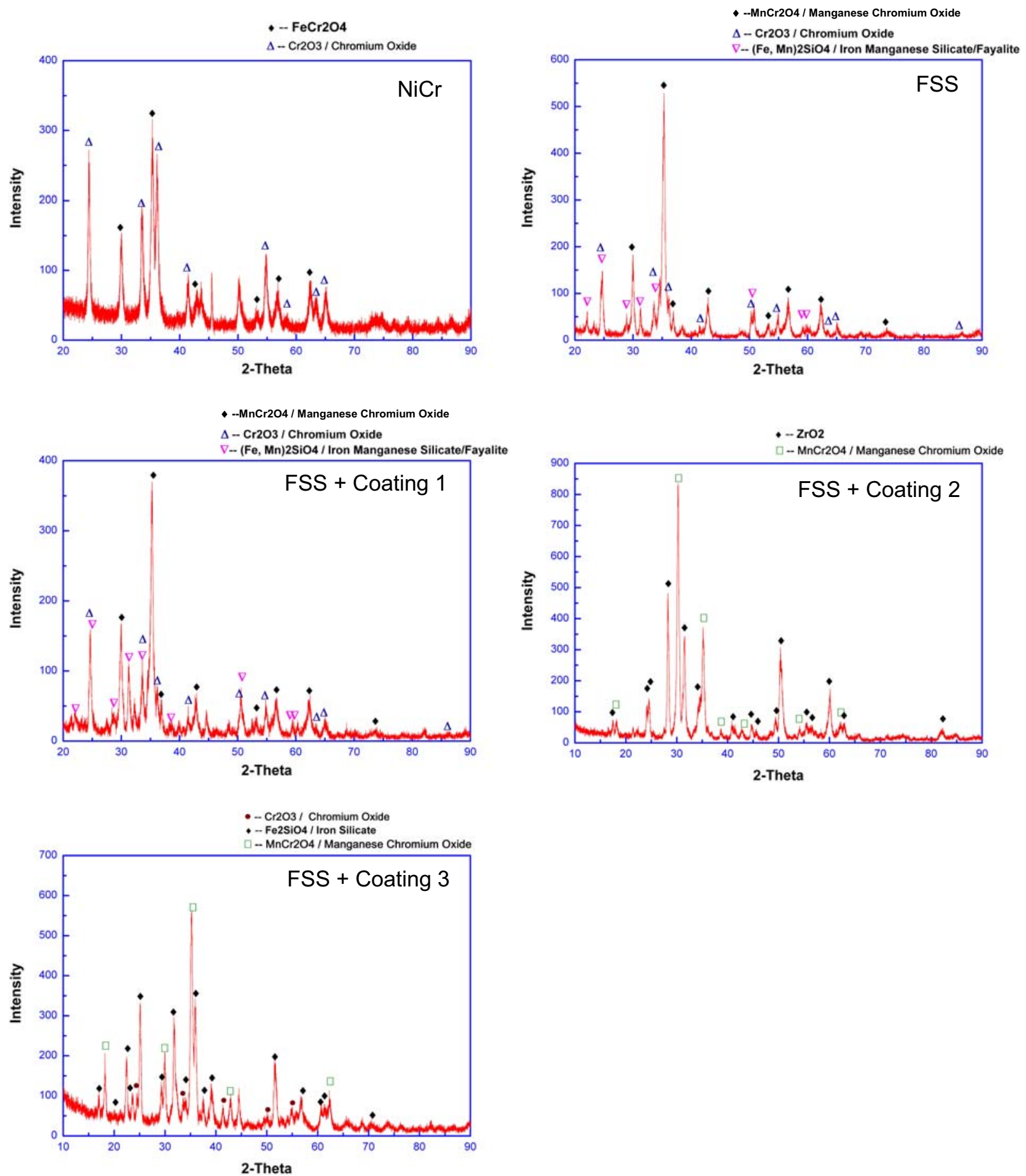

Figure 22. Grazing incidence $x$-ray diffraction patterns for samples exposed to $\mathrm{H}_{2} \mathrm{O} / \mathrm{H}_{2} / \mathrm{N}_{2}$ mixtures $\left(\mathrm{H}_{2} \mathrm{O} / \mathrm{H}_{2}=5\right)$ at $850^{\circ} \mathrm{C}$ for $500 \mathrm{~h}$ (Test 1$)$. 
Table 8. Crystalline phases at corroded sample surfaces identified with GIXRD. Samples were exposed to $\mathrm{H}_{2} \mathrm{O} / \mathrm{H}_{2} / \mathrm{N}_{2}$ mixtures $\left(\mathrm{H}_{2} \mathrm{O} / \mathrm{H}_{2}=5\right)$ at $850^{\circ} \mathrm{C}$ for $500 \mathrm{~h}$ (Test 1). Additional ceramic oxide phases (present in the as-prepared coatings) were also observed on the FSS specimens with Coating 2 and Coating 3.

\begin{tabular}{|l|c|c|c|c|c|}
\hline \multicolumn{1}{|c|}{ Sample } & $\mathrm{Cr}_{2} \mathbf{O}_{3}$ & $\mathbf{F e C r}_{2} \mathbf{O}_{4}$ & $\mathbf{M n C r}_{2} \mathbf{O}_{4}$ & $\mathbf{F e}_{2} \mathbf{S i O}_{4}$ & $(\mathbf{F e}, \mathbf{M n})_{2} \mathbf{S i O}_{4}$ \\
\hline NiCr & $\mathrm{X}$ & $\mathrm{X}$ & & & \\
\hline FSS & $\mathrm{X}$ & & $\mathrm{X}$ & & $\mathrm{X}$ \\
\hline FSS + Coating 1 & $\mathrm{X}$ & & $\mathrm{X}$ & & $\mathrm{X}$ \\
\hline FSS + Coating 2 & & & $\mathrm{X}$ & & \\
\hline FSS + Coating 3 & $\mathrm{X}$ & & $\mathrm{X}$ & $\mathrm{X}$ & \\
\hline
\end{tabular}

\subsubsection{Air corrosion}

Scanning electron micrographs of sample surfaces after exposure in air at $850^{\circ} \mathrm{C}$ for $500 \mathrm{~h}$ (Test 5) are shown in Figure 23-Figure 25.

The GIXRD patterns for uncoated FSS and NiCr exposed to air (Test 3) are shown in Figure 26. The NiCr specimen exhibited the same distribution of phases as the similar specimen exposed to steam/hydrogen (Test 1; see Figure 22). The FSS exhibited the presence of $\mathrm{Cr}_{2} \mathrm{O}_{3}$ and $\mathrm{MnCr}_{2} \mathrm{O}_{4}$, as with the $\mathrm{H}_{2} \mathrm{O} / \mathrm{H}_{2}$ exposed sample. However, the $(\mathrm{Fe}, \mathrm{Mn})_{2} \mathrm{SiO}_{4}$ phase found on the Test 1 sample (see Figure 22) has been replaced with $\mathrm{TiO}_{2}$. EDS data from the surface of this specimen confirms the presence of Ti.

The surface microstructure of the FSS + Coating 2 specimen is similar to that observed on both the as-received (Figure 13) and $\mathrm{H}_{2} \mathrm{O} / \mathrm{H}_{2}$ corroded (Figure 18) samples. The microstructure of the FSS + Coating 3 specimen (Figure 25) is significantly different from that of the $\mathrm{H}_{2} \mathrm{O} / \mathrm{H}_{2}$ corroded specimen (Figure 19), but no XRD is yet available to identify the oxide phases present on this specimen.
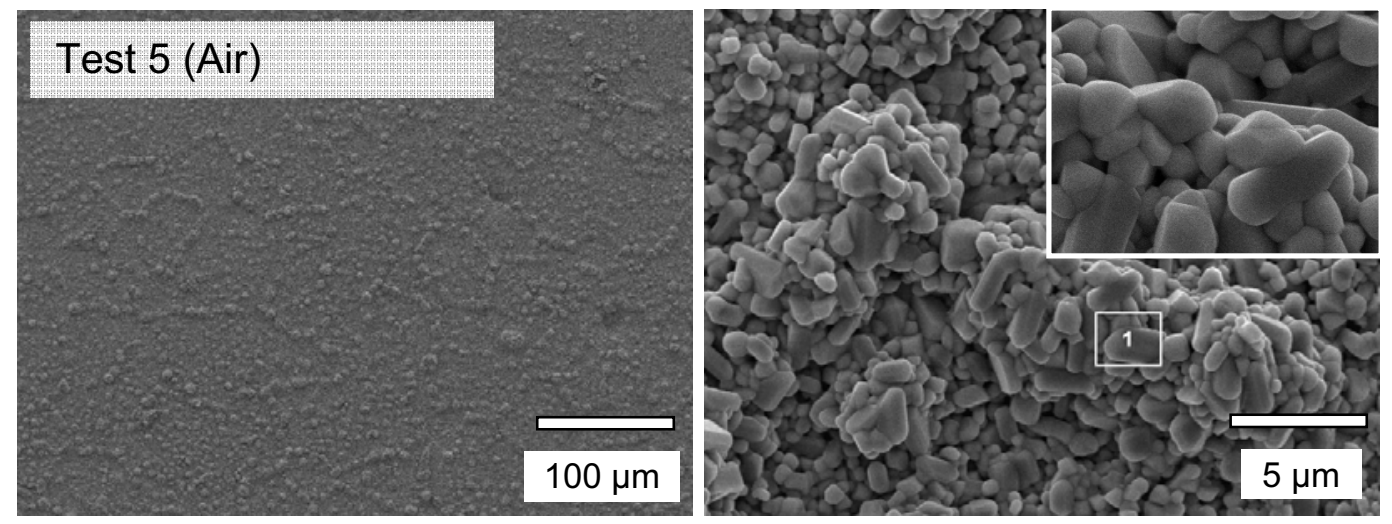

Figure 23. Surface micrographs of uncoated FSS exposed to dry air at $850^{\circ} \mathrm{C}$ for $500 \mathrm{~h}$ (Test 5). 

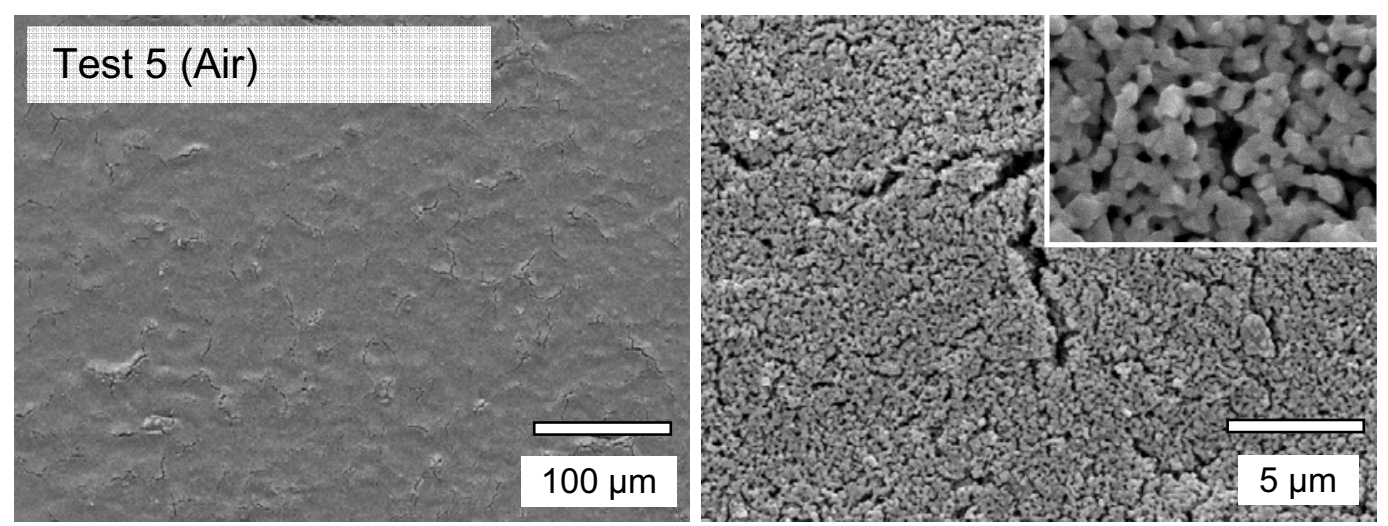

Figure 24. Surface micrographs of FSS + Coating 2 exposed to dry air at $850^{\circ} \mathrm{C}$ for $500 \mathrm{~h}$ (Test $3)$.
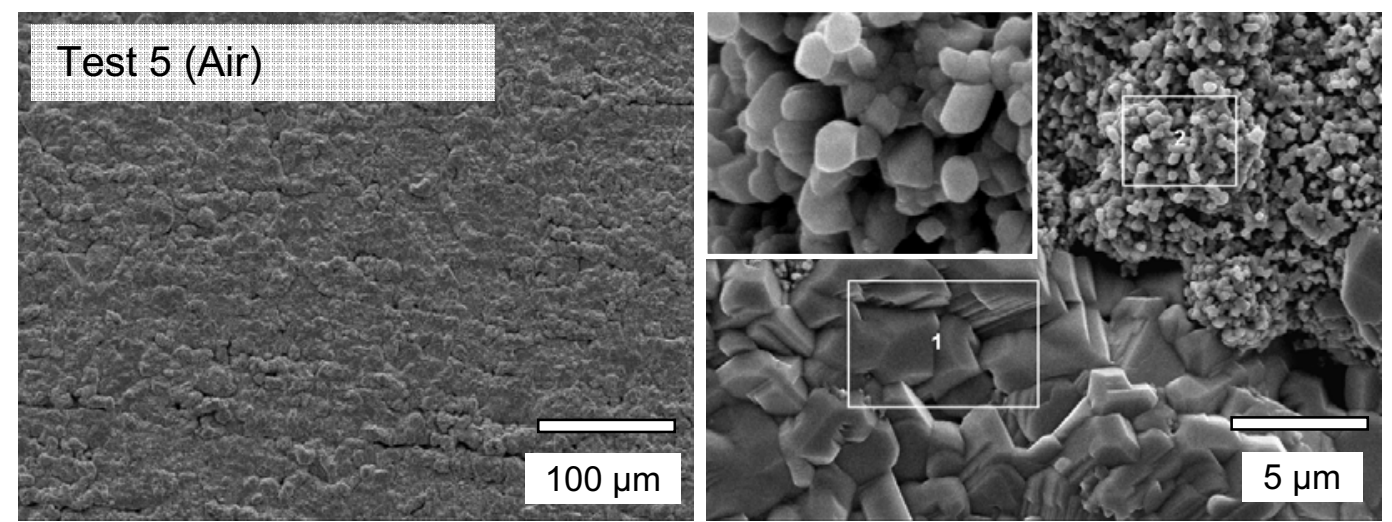

Figure 25. Surface micrographs of FSS + Coating 3 exposed to dry air at $850^{\circ} \mathrm{C}$ for $500 \mathrm{~h}$ (Test $3)$.
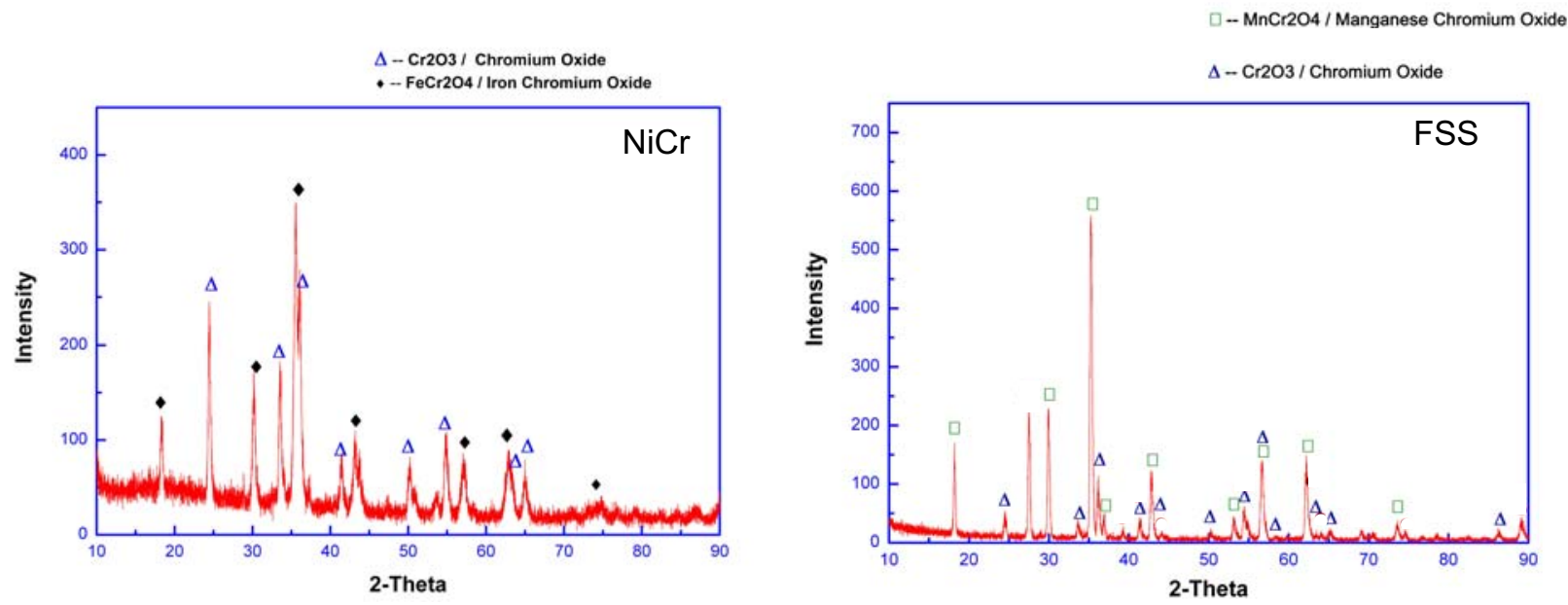

Figure 26. GIXRD patterns for $\mathrm{NiCr}$ and FSS after $500 \mathrm{~h}$ exposure to air at $850^{\circ} \mathrm{C}$ (Test 3 ). 


\section{4. $\quad$ ASR measurements}

Figure 27 shows a plot of the ASR measurements for the FSS and FSS + Coating 1 specimens from Test $2\left(\mathrm{H}_{2} \mathrm{O} / \mathrm{H}_{2}=0.5\right)$. Figure 28 shows the ASR data for a FSS + Coating 3 specimen from Test 3 (air). The results have shown good reproducibility upon heating and cooling at high temperatures (between $500^{\circ} \mathrm{C}$ and $1000^{\circ} \mathrm{C}$ ). However, at lower temperatures an increase in resistance values has been observed while repeating the ASR measurements. The reason for this behavior is being investigated. Figure 27 indicates that the resistance of the oxide layers on the coated and uncoated steel was identical above $800^{\circ} \mathrm{C}$ with values between about $0.2-0.25 \Omega \mathrm{cm}^{2}$, and that the rare-earth coated sample had slightly lower resistance below $800^{\circ} \mathrm{C}$. The resistance across the FSS + Coating 1 specimen heated in air (Figure 28) is again the same above $800^{\circ} \mathrm{C}$ as the value for the sample heated in $\mathrm{H}_{2} \mathrm{O} / \mathrm{H}_{2}$. However, below $800^{\circ} \mathrm{C}$ the resistance is slightly higher compared to the sample heated in $\mathrm{H}_{2} \mathrm{O} / \mathrm{H}_{2}$.

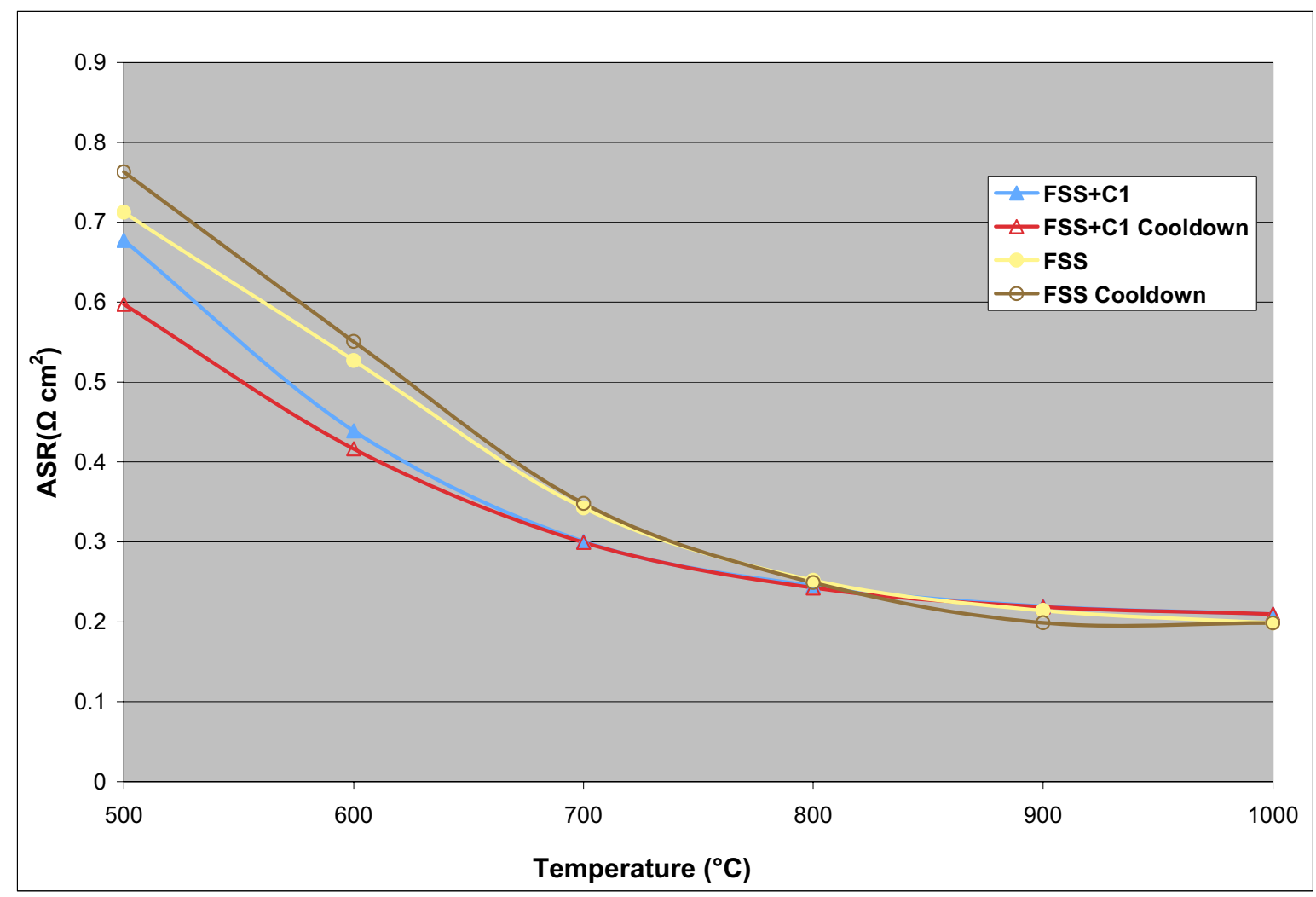

Figure 27. ASR measurements of FSS and FSS + Coating 1 specimens, performed after specimens were heated in steam/hydrogen $\left(\mathrm{H}_{2} \mathrm{O} / \mathrm{H}_{2}=0.5\right)$ at $850^{\circ} \mathrm{C}$ for 500 hours (Test 2). 


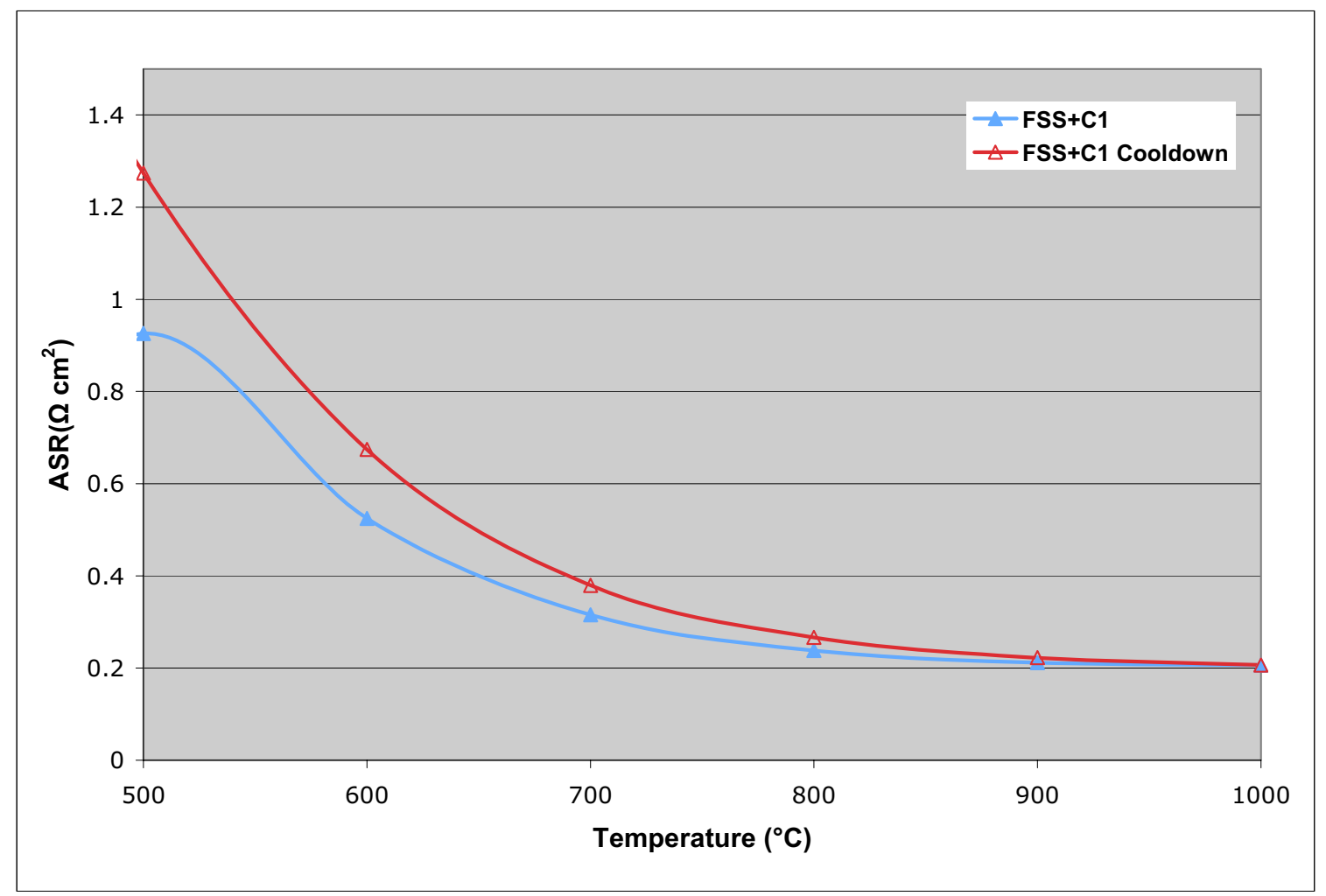

Figure 28. ASR measurements of a FSS + Coating 1 specimen, performed after specimens were heated in steam/hydrogen $\left(\mathrm{H}_{2} \mathrm{O} / \mathrm{H}_{2}=0.5\right)$ at $850^{\circ} \mathrm{C}$ for 500 hours (Test 3).

\section{Discussion}

\subsection{Untreated alloys}

The data on corrosion of uncoated $\mathrm{NiCr}$ and FSS specimens collected in this study are consistent with results presented in the literature, including:

- Superior corrosion performance of Ni-Cr alloys compared to $18-20 \% \mathrm{Cr}$ ferritic stainless steels under the test conditions explored in this work. ${ }^{9}$

- Parabolic rate constants determined for these two alloys. The values determined here are in the range of values presented in the literature $(9,10)$ for similar alloys.

- The presence of $\mathrm{Cr}_{2} \mathrm{O}_{3}$ and $\mathrm{FeCr}_{2} \mathrm{O}_{4}$ on the surface of corroded Ni-Cr alloys. ${ }^{10}$

In addition, the corrosion microstructures observed for the uncoated FSS specimens (Figure 16, Figure 23), in which there appears to be a thicker layer of scale along the metal grain boundaries, has been observed previously for high-chrome steels ${ }^{11}$, and has been attributed to Cr-rich phases forming on the surface at the grain boundaries. It has not yet been confirmed in this work if the thicker phases at the grain boundaries in these specimens are Cr-rich. 


\subsection{Coating performance}

Interpretation of coating performance will be difficult until post-test characterization data from all of the tests is available. The results have indicated that the coatings on the FSS material reduced corrosion rates in $\mathrm{H}_{2} \mathrm{O} / \mathrm{H}_{2}$ atmospheres, but not in air. The GIXRD data for samples heated in $\mathrm{H}_{2} \mathrm{O} / \mathrm{H}_{2}$ do not provide any indication as to why the coatings reduced corrosion rates. Both the uncoated and coated FSS specimens (with the exception of Coating 2) exhibited the presence of $\mathrm{Cr}_{2} \mathrm{O}_{3}, \mathrm{MnCr}_{2} \mathrm{O}_{4}$, and an iron or iron/manganese silicate phase. X-ray diffraction data from the air-corroded samples will be useful in order to compare the oxide corrosion scales with those formed during the $\mathrm{H}_{2} \mathrm{O} / \mathrm{H}_{2}$ tests, and help determine the reasons for the differing behavior.

Coating 2 is the only coating that exhibited weight gains that were statistically lower than the other coatings, and only in the air tests. The reason for this behavior is not yet known. Coating 2 appeared to be thicker than either of the other two coatings. It is possible that this porous layer limited diffusion of gas species to and from the substrate surface and therefore slowed the reaction rates. The XRD data from the air tests will help to better explain this behavior.

The differences in corrosion of the coated samples from Lot 1 and Lot 2 also cannot be easily explained from the available data without a knowledge of possible variables in the coating process. Further testing on samples from different coating lots would be necessary to explore this issue in more detail.

The initial ASR measurements indicate that resistivities of specimens with Coating 1 are very similar to those of the uncoated steel, and above $800^{\circ} \mathrm{C}$ the values appear to be identical for the two types of specimens. This is consistent with the current XRD data (Figure 22, Table 8), which indicate that the oxide layers present on the FSS and FSS + Coating 1 specimens heated in $\mathrm{H}_{2} \mathrm{O} / \mathrm{H}_{2}$ are the same (i.e. $\mathrm{Cr}_{2} \mathrm{O}_{3}, \mathrm{MnCr}_{2} \mathrm{O}_{4}$, and $(\mathrm{Fe}, \mathrm{Mn})_{2} \mathrm{SiO}_{4}$ ). While the weight gain data suggests that the oxide scale thickness on the uncoated FSS is as much as twice that of the specimens with Coating 1, the resistance of the uncoated FSS is only slightly higher at temperatures down to $500^{\circ} \mathrm{C}$. As noted in the results section, XRD data indicate that the (RE) $\mathrm{CrO}_{3}$ layer present on the as-treated FSS + Coating 1 specimens was not observed on the corroded samples. While it is not yet known if the $(\mathrm{RE}) \mathrm{CrO}_{3}$ is present beneath the other oxide layers and therefore undetectable to the low-angle x-rays, the replacement of this relatively high conductivity layer with $\mathrm{Cr}_{2} \mathrm{O}_{3}, \mathrm{MnCr}_{2} \mathrm{O}_{4}$, and (Fe,Mn) ${ }_{2} \mathrm{SiO}_{4}$ could explain the apparently low effectiveness of the lanthanum coating in reducing resistance.

\section{Summary}

The pertinent results observed to date on the air and steam/hydrogen corrosion of $\mathrm{NiCr}$ and FSS with and without surface treatments are summarized below:

- The corrosion data for the untreated alloys is consistent with results presented previously in the literature.

- The steel coatings reduced corrosion in $\mathrm{H}_{2} \mathrm{O} / \mathrm{H}_{2}$ mixtures by as much as $50 \%$ compared to the untreated steel, while the coatings resulted in essentially no improvement in corrosion behavior in air. 
- There was a noticeable difference in corrosion behavior of coatings from different lots, indicating a variation in the process. The limited amount of weight gain data for coatings from Lot 2 demonstrated that corrosion rates are reduced in both air and $\mathrm{H}_{2} \mathrm{O} / \mathrm{H}_{2}$ compared to the results obtained for the Lot 1 samples. This indicates that the effectiveness of the coatings at reducing corrosion rates could be greater than demonstrated in this work with the data from the Lot 1 samples.

- The rare-earth coating on FSS did not have a significant effect on through-sample resistance after $\mathrm{H}_{2} \mathrm{O} / \mathrm{H}_{2}$ corrosion. The area specific resistance of the FSS + Coating 1 specimen is slightly lower than the untreated steel between $500-800^{\circ} \mathrm{C}$, and identical between $800-1000^{\circ} \mathrm{C}$ for specimens heated in $\mathrm{H}_{2} \mathrm{O} / \mathrm{H}_{2}$.

The characterization of corroded samples is currently continuing. The complete set of data will allow a more comprehensive understanding of the corrosion behavior.

\section{REFERENCES}

1. R. Hino, Katsuhiro Haga, Hideki Aita, and Kenji Sekita, "R\&D on hydrogen production by high-temperature electrolysis of steam," Nuclear Engineering and Design, 233 (2004) 363

2. J.E. O’Brien, C.M. Stoots, J.S. Herring, P.A. Lessing, J.J. Hartvigsen, and S. Elangovan, "Performance measurements of solid-oxide electrolysis cells for hydrogen production," Journal of Fuel Cell Science and Technology, 2 (2005) 156

3. Prabhakar Singh and Nguyen Q. Minh, "Solid oxide fuel cells: technology status," Applied Ceramic Technology, 1 (2004) 5

4. Osamu Yamamoto, "Solid oxide fuel cells: fundamental aspects and prospects," Electrochimica Acta, 45 (2000) 2423

5. W.Z. Zhu and S.C. Deevi, "Development of interconnect materials for solid oxide fuel cells," Materials Science and Engineering A, 348 (2003) 227

6. W.J. Quadakkers J. Piron-Abellan, V. Shemet, and L. Singheiser, "Metallic interconnectors for solid oxide fuel cells - a review," Materials at High Temperatures., 20, 115 (2003)

7. J. Stepehn Herring, James E. O'Brien, Carl M. Stoots, G.L. Hawkes, Joseph J. Hartvigsen, and Mehrdad Shanham, "Progress in High-Temperature Electrolysis for Hydrogen Production using Planar SOFC Technology," International Journal of Hydrogen Energy, 32 (2007) 440

8. J.E. O'Brien, C.M. Stoots, J.S. Herring, and J. Hartvigsen, "Hydrogen production performance of a 10-cell planar solid-oxide electrolysis stack," Journal of Fuel Cell Science and Technology, 3 (2006) 213

9. Jeffrey W. Fergus, "Metallic interconnects for solid oxide fuel cells," Materials Science and Engineering A, 397 (2005) 271-283

10. Diane M. England and Anil V. Virkar, "Oxidation kinetics of some nickel-based superalloy foils in humidified hydrogen and electronic resistance of the oxide scale formed, Part II," Journal of the Electrochemical Society, 148 (2001) A330-A338

11. V.B. Trindade, U. Krupp, Ph.E.-G. Wagenhuber, and H.-J. Christ, "Oxidation mechanisms of Cr-containing steels and Ni-base alloys at high-temperatures. Part I: The different role of alloy grain boundaries," Materials and Corrosion, 56 (2005) 785-790 